\title{
Role of Machine Learning Techniques to Tackle the COVID-19 Crisis: Systematic Review
}

Hafsa Bareen Syeda ${ }^{1 *}$, MD; Mahanazuddin Syed ${ }^{2 *}$, MS; Kevin Wayne Sexton ${ }^{2,3,4}$, MD; Shorabuddin Syed ${ }^{2}$, MS; Salma Begum ${ }^{5}$, MS; Farhanuddin Syed ${ }^{6}$, MD; Fred Prior ${ }^{2,7}$, PhD; Feliciano Yu Jr ${ }^{2}$, MD

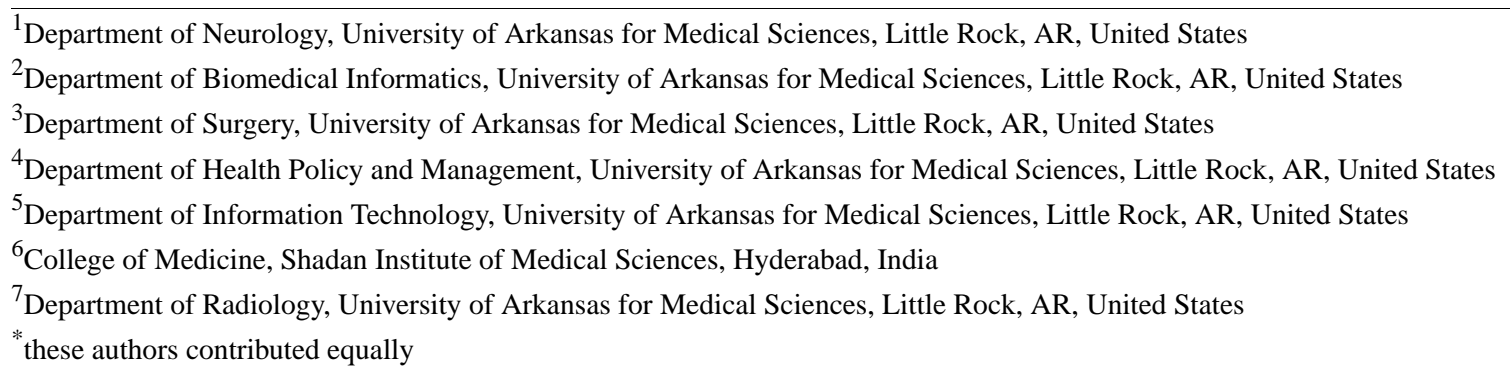

Corresponding Author:

Shorabuddin Syed, MS

Department of Biomedical Informatics

University of Arkansas for Medical Sciences

4301 W Markham \#469

Little Rock, AR, 72205

United States

Phone: 15016131443

Email: ssyed@uams.edu

\section{Abstract}

Background: SARS-CoV-2, the novel coronavirus responsible for COVID-19, has caused havoc worldwide, with patients presenting a spectrum of complications that have pushed health care experts to explore new technological solutions and treatment plans. Artificial Intelligence (AI)-based technologies have played a substantial role in solving complex problems, and several organizations have been swift to adopt and customize these technologies in response to the challenges posed by the COVID-19 pandemic.

Objective: The objective of this study was to conduct a systematic review of the literature on the role of AI as a comprehensive and decisive technology to fight the COVID-19 crisis in the fields of epidemiology, diagnosis, and disease progression.

Methods: A systematic search of PubMed, Web of Science, and CINAHL databases was performed according to PRISMA (Preferred Reporting Items for Systematic Reviews and Meta-Analysis) guidelines to identify all potentially relevant studies published and made available online between December 1, 2019, and June 27, 2020. The search syntax was built using keywords specific to COVID-19 and AI.

Results: The search strategy resulted in 419 articles published and made available online during the aforementioned period. Of these, 130 publications were selected for further analyses. These publications were classified into 3 themes based on AI applications employed to combat the COVID-19 crisis: Computational Epidemiology, Early Detection and Diagnosis, and Disease Progression. Of the 130 studies, $71(54.6 \%)$ focused on predicting the COVID-19 outbreak, the impact of containment policies, and potential drug discoveries, which were classified under the Computational Epidemiology theme. Next, 40 of 130 (30.8\%) studies that applied AI techniques to detect COVID-19 by using patients' radiological images or laboratory test results were classified under the Early Detection and Diagnosis theme. Finally, 19 of the 130 studies (14.6\%) that focused on predicting disease progression, outcomes (ie, recovery and mortality), length of hospital stay, and number of days spent in the intensive care unit for patients with COVID-19 were classified under the Disease Progression theme.

Conclusions: In this systematic review, we assembled studies in the current COVID-19 literature that utilized AI-based methods to provide insights into different COVID-19 themes. Our findings highlight important variables, data types, and available COVID-19 resources that can assist in facilitating clinical and translational research. 
(JMIR Med Inform 2021;9(1):e23811) doi: 10.2196/23811

\section{KEYWORDS}

COVID-19; coronavirus; SARS-CoV-2; artificial intelligence; machine learning; deep learning; systematic review; epidemiology; pandemic; neural network

\section{Introduction}

COVID-19 is a global health crisis, with more than 16 million people infected and over 666,000 deaths reported (up to July $29,2020)$ worldwide [1]. The resulting impact on health care systems is that many countries have overstretched their resources to mitigate the spread of the pandemic [2]. In addition, a high degree of variance in COVID-19 symptoms has been reported, with symptoms ranging from a mild flu to acute respiratory distress syndrome (ARDS) or fulminant pneumonia [3-5]. There is an urgent need for effective drugs and vaccines for COVID-19 treatment and prevention. Owing to the lack of validated therapeutics, most containment measures to curtail the spread of the disease rely on social distancing, quarantine measures, and lockdown policies $[2,6]$. The transmission of COVID-19 has been slowed as a result of these measures, but not eliminated. Moreover, with the ease of restrictions, a fear of the second wave of infection is prevalent $[7,8]$. To prevent the second potential outbreak of COVID-19, there is a need for advanced containment measures such as contact tracing and identification of hotspots $[9,10]$.

Artificial intelligence (AI) encompasses a broad spectrum of technologies that aim to imitate cognitive functions and intelligent behavior of humans [11]. Machine learning (ML) is a subfield of AI that focuses on algorithms that enable computers to define a model for complex relationships or patterns from empirical data without being explicitly programmed [11]. Deep learning (DL), a subcategory of ML, achieves great power and flexibility compared to conventional ML models by drawing inspiration from biological neural networks to solve a wide variety of complex tasks, including the classification of medical imaging and natural language processing (NLP) [11].

AI techniques have been employed in the health care domain on different scales ranging from the prediction of disease spread trajectory to the development of diagnostic and prognostic models [12-14]. A study by Ye et al [15] identified and evaluated various health technologies, such as big data, cloud computing, mobile health, and AI, to fight the pandemic. These technologies and a wide range of data types, including data from social media, radiological images, omics, drug databases, and public health agencies, have been used for disease prediction [1,14,16-19]. Several studies have focused on reviewing publications that discuss AI applications to support the COVID-19 response [12,13,15,20,21]. One of the early studies by Vaishya et al [20] identified 7 critical areas where AI can be applied to monitor and control the COVID-19 pandemic. However, given that this was an early work, this review lacked publications in all the 7 areas. In a later study, Lalmuanawma et al [12] built upon these 7 areas by identifying and performing a rapid review of the then available studies; however, considering this was a rapid review, only limited studies were included, and the qualification criteria were not clear. Furthermore, a study by Shi et al [21] focused on AI applications to radiological images, and a study by Wynants et al [13] focused on critical appraisal of models that aimed to predict the risk of developing the disease, hospital admission, and disease progression. Nevertheless, the majority of epidemiological studies that aimed to model disease transmission or fatality rate, among other factors, were excluded in this study.

The primary aim of this study was to conduct a comprehensive systematic literature review on the role of $\mathrm{AI}$ as a technology to combat the COVID-19 crisis and to assess its application in the epidemiological, clinical, and molecular advancements. Specifically, we summarized the areas of AI application, data types used, types of AI methods employed and their performance, scientific findings, and challenges experienced in adopting this technology.

\section{Methods}

This systematic literature review followed the guidelines of PRISMA (Preferred Reporting Items for Systematic Reviews and Meta-Analyses) framework for preparation and reporting [22].

\section{Eligibility Criteria}

This study focused on peer-reviewed publications as well as preprints that applied AI techniques to analyze and address the COVID-19 crisis on different scales, including diagnostics, prognostics, disease spread forecast, omics, and drug development.

\section{Data Sources and Search Strategy}

PubMed, Web of Science, and CINAHL databases were searched, restricting the search to research articles published in English and in peer-reviewed or preprint journals or conference proceedings available from Dec 1, 2019, through June 27, 2020. The search syntax was built with the guidance of a professional librarian and included the following search terms: "CORONAVIRUS," “COVID-19," “covid19," “cov-19," "cov19," "severe acute respiratory syndrome coronavirus 2," "Wuhan coronavirus," "Wuhan seafood market pneumonia virus," "coronavirus disease 2019 virus," "SARS-CoV-2," "SARS2," "SARS-2," "2019-nCoV," "2019 novel coronavirus," "novel corona," "Machine Learning," "Artificial Intelligence," "Deep Learning," "Neural Network," "Random Forest," "Support Vector Machine," and "SVM." Refer to Multimedia Appendix 1 for search query syntax. Figure 1 illustrates the process of identifying eligible publications. 
Figure 1. PRISMA (Preferred Reporting Items for Systematic Reviews and Meta-Analysis) flow diagram of systematic identification, screening, eligibility, and inclusion of publications that applied artificial intelligence techniques to tackle the COVID-19 pandemic.

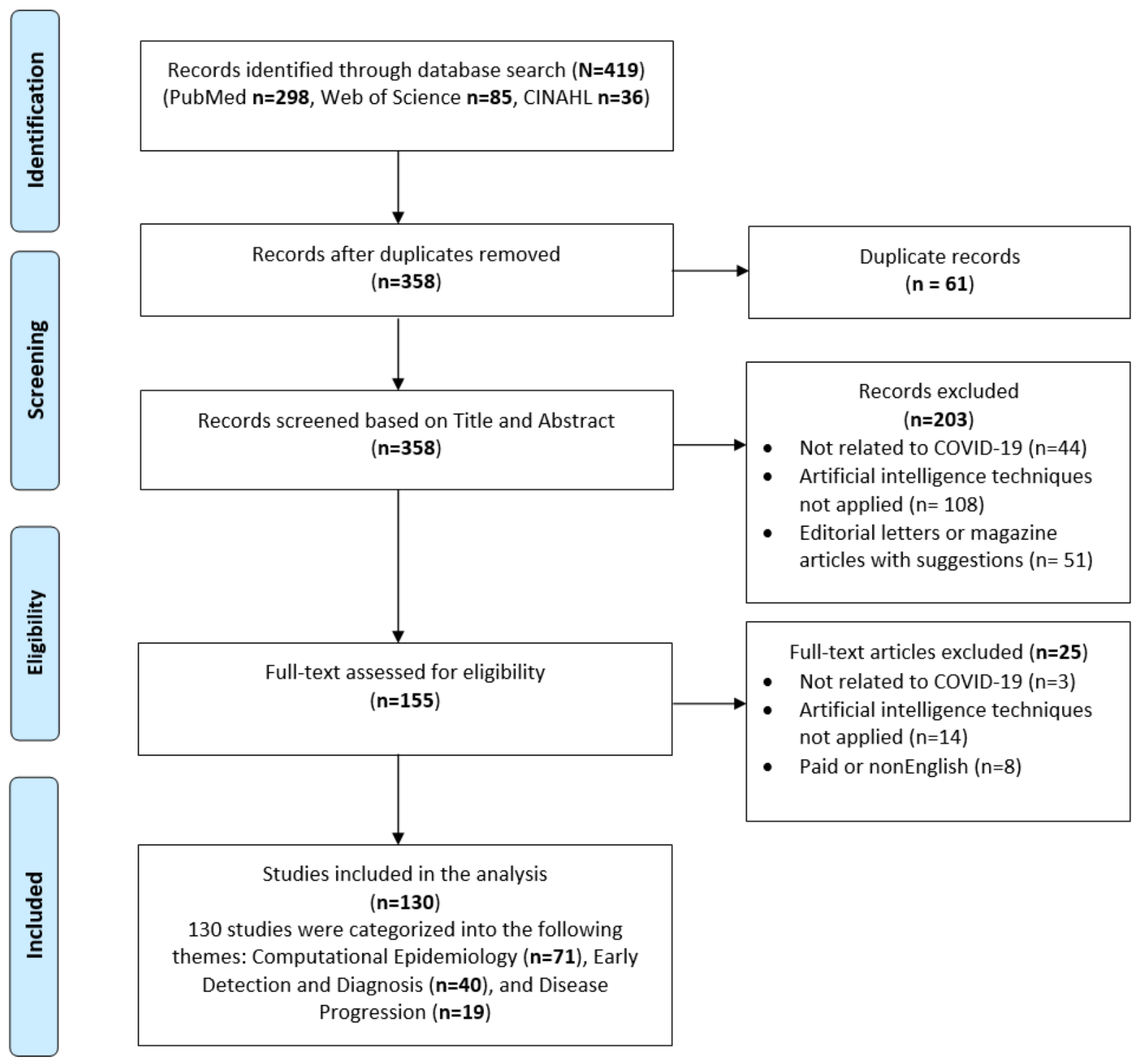

\section{Study Selection}

Following the systematic search process, 419 publications were retrieved. Of that, 61 duplicate publications were removed, leaving 358 potentially relevant articles for title and abstract screening. Two teams of reviewers (HB, SS and MS, SB) screened these articles independently, following which an additional 203 publications were removed, and 155 publications were retained for a full-text assessment. These publications were further assessed for eligibility, resulting in a total of 130 publications that were included in the final analysis. Disagreements between reviewers were resolved by an independent review by a third reviewer (FS).

\section{Data Collection and Analyses}

Qualitative and quantitative descriptive analyses were performed on the included studies $(n=130)$ that had used AI techniques for tackling the COVID-19 pandemic. Based on the area of application, the studies were categorized into the following 3 themes: (1) Computational Epidemiology (CE), (2) Early Detection and Diagnosis (EDD), and (3) Disease Progression (DP). Qualitative analysis was performed on studies that belonged to the $\mathrm{CE}$ theme and quantitative descriptive analysis was performed for studies that belonged to the EDD and DP themes. After data extraction and analysis, we summarized and reported the findings in the form of tables and figures in accordance with the aim of the study.

\section{Results}

\section{Search Results}

The search strategy yielded a total of 419 articles, which were published and made available between December 1, 2019, and June 27, 2020. Of which, 130 publications were selected for further analyses. These 130 publications were categorized into 3 themes (ie, CE, EDD, and DP) based on the various AI applications employed to combat the COVID-19 crisis. These themes were identified based on AI techniques used to predict, 
classify, assess, track, and control the spread of the virus. Descriptions of each theme and related publications are presented in Table 1.

During the initial days of the COVID-19 outbreak, the majority of published studies focused on predicting the outbreak and potential drug discoveries; we identified 71 such studies and classified them into the CE theme. Furthermore, 40 studies that applied AI techniques to detect COVID-19 using patients' radiological images or laboratory test results were grouped under the EDD theme. Finally, 19 studies that focused on predicting disease progression, outcomes (recovery and mortality), length of stay, and the number of days spent in the intensive care unit (ICU) for patients with COVID-19 were grouped under the DP theme. Over time trend of COVID-19 publications by month and themes is shown in Figure 2, which depicts an initial surge of publications focusing on the CE theme followed by the EDD theme.

Table 1. An overview of the 130 publications in the literature, classified into 3 themes and their descriptions. The themes are listed according to the frequency of publication (percentage and absolute count).

\begin{tabular}{llll}
\hline Theme & Description & References & Publication count, $\mathrm{n}(\%)$ \\
\hline Computational Epidemiology & $\begin{array}{l}\text { Publications focused on the development and application } \\
\text { of artificial intelligence models to tackle issues central to } \\
\text { epidemiology, such as disease trends and forecast of poten- } \\
\text { tial outbreak, pathobiology of coronavirus infection, protein } \\
\text { structures, potential drug discoveries, policies, and social } \\
\text { impact. }\end{array}$ & $\begin{array}{l}\text { [14,16,18,23-90] } \\
\text { Early Detection and Diagnosis }\end{array}$ \\
& $\begin{array}{l}\text { Publications focused on the application of artificial intelli- } \\
\text { gence techniques to detect and differentiate patients with }\end{array}$ & [91-130] \\
& $\begin{array}{l}\text { COVID-19 from the general population. } \\
\text { Publications focused on the application of artificial intelli- } \\
\text { Disease Progression }\end{array}$ & $\begin{array}{l}\text { [17,131-148] } \\
\text { gence models to predict disease progression, severity, and } \\
\text { likely outcomes in the confirmed COVID-19 population. }\end{array}$ & 19(14.6) \\
\hline
\end{tabular}

Figure 2. Over time (trend analysis) of COVID-19 studies focused on the application of artificial intelligence techniques that were made available online in 2020, categorized into the following 3 themes: (1) Computational Epidemiology (CE), (2) Early Detection and Diagnosis (EDD), and (3) Disease Progression (DP). For preprint articles, the publication month of the latest version available as of query search date was used.

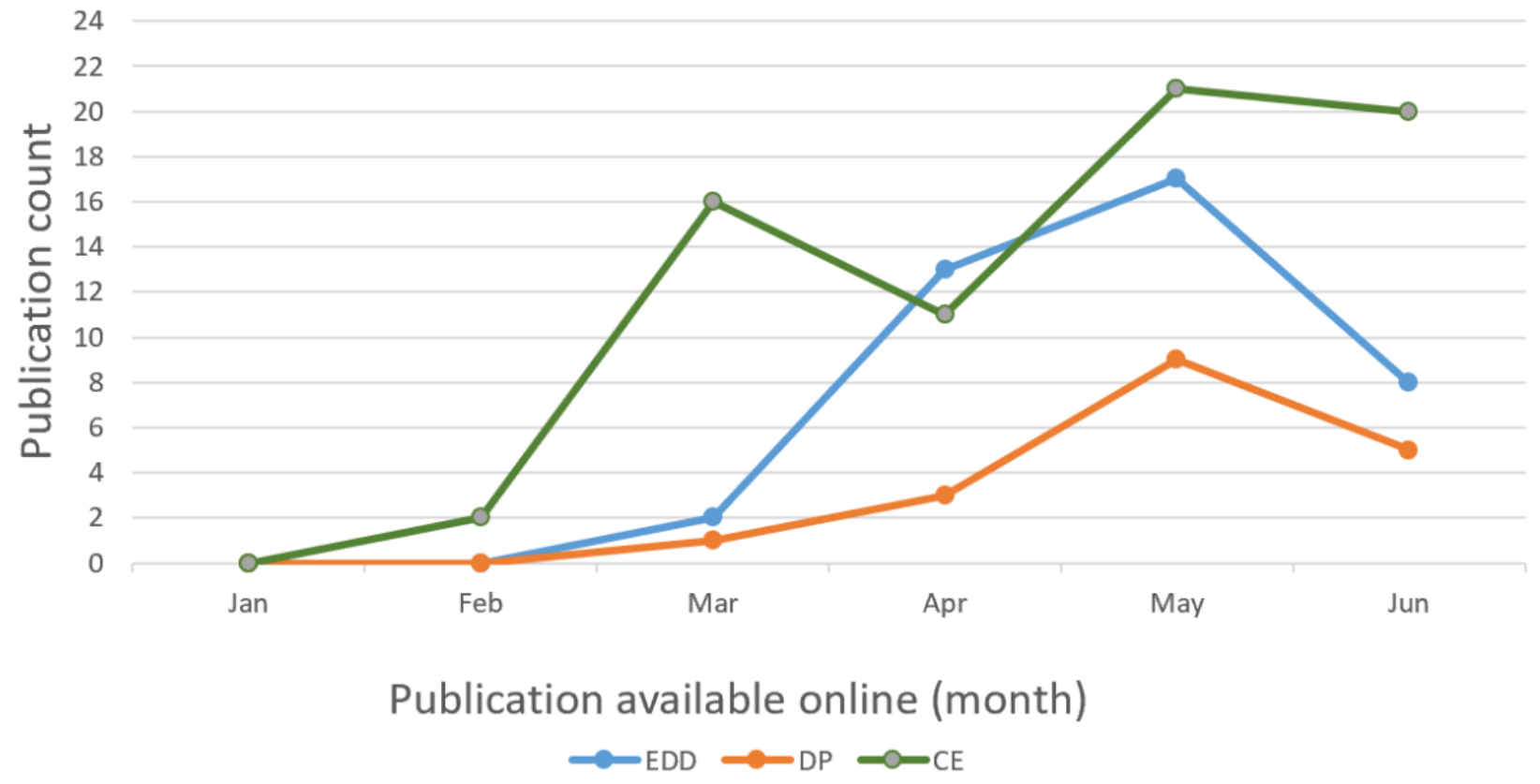

\section{Publications Focused on CE}

The 71 studies that focused on epidemiological concerns of COVID-19 were further classified into 3 categories: (1) COVID-19 disease trajectory (CDT), (2) molecular analysis-drug discovery (MADD), and (3) facilitate COVID-19 response (FCR). These classifications were based on the study aims, that is, to predict outbreaks, potential drug discoveries, policies, and other measures to contain the spread of COVID-19 (see Table 2). In all, 40 studies that focused on predicting COVID-19 peaks and sizes globally and specific to a geographical location, estimating the impact of socioeconomic factors and environmental conditions on the spread of the disease, and effectiveness of social distancing policies in containing disease spread were categorized under CDT. Next, 22 publications were grouped under MADD based on the study approach used, including studies focused on identification of existing drugs that have the potential to treat COVID-19, 
analysis of protein structure, and prediction of mutation rate in patients with COVID-19. Finally, 9 studies that emphasized on building tools to combat the ongoing pandemic, such as building a COVID-19 imaging repository, AI-enabled automatic cleaning and sanitizing tasks at health care facilities that might assist clinical practitioners to provide timely services to the affected population, were categorized under FCR. The majority of publications classified under the $\mathrm{CE}$ theme used data from either social media (eg, 9 studies used data from Twitter, Weibo, or Facebook) or public data repositories (Eg, NCBI, DrugBank databases, and other health agencies). Details of individual studies are provided in Multimedia Appendix 2.

Table 2. Computational Epidemiology publications ( $n=71$ ) subclassified into 3 categories: (1) COVID-19 disease trajectory, (2) molecular analysis-drug discovery, and (3) facilitate COVID-19 response.

\begin{tabular}{|c|c|c|c|}
\hline Category & Description & References & Publication count, $\mathrm{n}(\%)$ \\
\hline COVID-19 disease trajectory & $\begin{array}{l}\text { Publications focused on predicting COVID-19 peaks and } \\
\text { sizes globally (and specific to a geographical location), } \\
\text { estimating the impact of socioeconomic factors and envi- } \\
\text { ronmental conditions on the spread of the disease, and ef- } \\
\text { fectiveness of social distancing policies in containing dis- } \\
\text { ease spread. }\end{array}$ & [23-62] & $40(56.3)$ \\
\hline Molecular analysis: drug discovery & $\begin{array}{l}\text { Publications focused on identifying existing drugs that have } \\
\text { the potential to treat COVID- } 19 \text {, analysis of protein struc- } \\
\text { ture, and predicting mutation rate in patients with COVID- } \\
19 \text {. }\end{array}$ & [69-89] & $22(31)$ \\
\hline Facilitate COVID-19 response & $\begin{array}{l}\text { Publications focused on building tools to combat the ongo- } \\
\text { ing pandemic, such as building a COVID-19 imaging } \\
\text { repository, artificial intelligence-enabled automatic clean- } \\
\text { ing and sanitizing tasks at health care facilities to assist } \\
\text { clinical practitioners to provide timely services to the af- } \\
\text { fected population. }\end{array}$ & {$[63-68,90]$} & $9(12.7)$ \\
\hline
\end{tabular}

\section{Publications Focused on EDD}

We identified 40 publications that primarily focused on diagnosing COVID-19 in patients with suspected infection mostly by using chest radiological images, such as computed tomography (CT), X-radiation (X-ray), and lung ultrasound (LUS). As shown in Table 3, 23 studies used X-ray, 15 used CT, 1 study used LUS, and 1 study used nonimaging clinical data. Most studies used DL techniques to diagnose COVID-19 based on radiological images. Nine studies employed ResNet, 4 studies used Xception, and 3 studies used VGG neural network models either for pretraining or as a diagnostic model. The only study that used nonimaging clinical data to diagnose COVID-19 employed routine laboratory results captured in electronic health record (EHR) systems. Details of individual studies are provided in Multimedia Appendix 3.

Table 3. Early Detection and Diagnosis publications ( $n=40)$ subclassified into 4 categories based on the modality used for COVID-19 prediction: (1) $\mathrm{X}$-ray, (2) computed tomography, (3) lung ultrasound, and 4) nonimaging clinical data.

\begin{tabular}{|c|c|c|c|}
\hline Category & Description & References & $\begin{array}{l}\text { Publication count, } \\
\mathrm{n}(\%)\end{array}$ \\
\hline X-ray & $\begin{array}{l}\text { Publications focused on the application of artificial intelli- } \\
\text { gence techniques to detect and differentiate patients with } \\
\text { COVID-19 from the general population using X-ray images. }\end{array}$ & $\begin{array}{l}{[91,92,95,97-99,101-106,} \\
112-114,117,118,122-124, \\
126,127,129]\end{array}$ & $23(57.5)$ \\
\hline Computed tomography & $\begin{array}{l}\text { Publications focused on the application of artificial intelli- } \\
\text { gence techniques to detect and differentiate patients with } \\
\text { COVID-19 from the general population using computed } \\
\text { tomography images. }\end{array}$ & $\begin{array}{l}{[93,94,96,100,107-111,} \\
116,119-121,125,130]\end{array}$ & $15(37.5)$ \\
\hline Lung ultrasound & $\begin{array}{l}\text { Publication focused on the application of artificial intelli- } \\
\text { gence techniques to detect and differentiate patients with } \\
\text { COVID-19 from the general population using lung ultra- } \\
\text { sound images. }\end{array}$ & [128] & $1(2.5)$ \\
\hline Nonimaging clinical data & $\begin{array}{l}\text { Publication focused on the application of artificial intelli- } \\
\text { gence techniques to detect and differentiate patients with } \\
\text { COVID-19 from the general population using nonimaging } \\
\text { clinical data. }\end{array}$ & [115] & $1(2.5)$ \\
\hline
\end{tabular}

\section{Publications Focused on DP}

We identified 19 publications that were primarily focused on the prognosis of disease in patients with COVID-19. We further classified these studies into (1) risk stratification $(n=15)$, which included publications focused on assessing the risk of DP and (2) hospital resource management $(n=4)$, which included publications focused on predicting the need for hospital 
resources (see Table 4). All 15 DP studies used demographic variables, 13 studies used comorbidities, and 11 studies used radiological images for analyses. Details of individual studies grouped under this theme are provided in Multimedia Appendix 4.

Table 4. Disease Progression publications subclassified into 2 categories: (1) risk stratification and (2) hospital resource management.

\begin{tabular}{llll}
\hline Category & Description & References & Publication count, $\mathrm{n}(\%)$ \\
\hline Risk stratification & $\begin{array}{l}\text { Publications focused on assessing the risk of disease } \\
\text { progression. }\end{array}$ & $\begin{array}{l}{[17,131,133,134,137-140,} \\
142-148]\end{array}$ & $15(78.9)$ \\
Hospital resource management & $\begin{array}{l}\text { Publications focused on predicting the need for hospital } \\
\text { resources. }\end{array}$ & {$[132,135,136,141]$} & $4(21.1)$ \\
\hline
\end{tabular}

\section{Discussion}

AI techniques will continue to be used for the monitoring, detection, and containment of the COVID-19 pandemic $[56,95,131]$. Our systematic review focused on 130 studies that applied AI methods and identified 3 broad themes: models developed to address issues central to epidemiology, models that aid the diagnosis of patients with COVID-19, and models that facilitate the prognosis of patients with COVID-19. The 7 areas of AI application areas as identified by Vaishya et al [20] were grouped into these themes, as described below.

\section{Theme 1: CE models}

In this theme, we review various AI techniques applied in different areas of epidemiology.

\section{AI Techniques for MADD}

\section{Current State of Drug Discovery for COVID-19}

Currently, there is no available vaccine for treating COVID-19 patients, and this has forced researchers to invent new strategies for expediting antiviral treatment and decreasing the mortality rate [149]. On average, the conventional drug discovery process takes 10-15 years and has very low success rates [150]. Instead, drug repurposing attempts have been made to explore similarities between SARS-CoV-2 (ie, the causative agent of COVID-19) and other viruses such as SARS and HIV [151]. With the rapid accumulation of genetic and other biomedical data in recent years, AI techniques facilitate the analyses of drugs and chemical compounds that are already available to find new therapeutic indications [152].

\section{Protein Structure Analysis}

The main protease (Mpro) of COVID-19 is a key enzyme in polyprotein processing, which plays an important role in mediating viral replication and transcription [153]. Several studies have applied AI techniques to identify drug leads that target Mpro of SARS-CoV-2, thereby making it an attractive drug target [154,155]. Ton et al [87] built a DL platform called Deep Docking, which enables structure - based virtual screening of billions of purchasable molecules in a short time. This platform was used to process more than 1 billion compounds available from the ZINC15 library in order to identify the top 1000 potential ligands for SARS - CoV - 2 Mpro. The proposed docking platform is a computationally cheaper and faster AI method than traditional docking methods, which allows faster screening of large chemical libraries containing billions of compounds.

\section{Drug Repurposing}

Beck et al [16] used a drug-target interaction DL model to identify the top 10 commercially available drugs that could act on viral proteins of SARS-CoV-2. The DL model called Molecule Transformer-Drug Target Interaction was used to predict binding affinity values between marketable antiviral drugs that could target COVID-19 proteins. The researchers claim that this model can accurately predict binding affinity based on chemical and amino acid sequences of a target protein without knowledge of their structural information. Moreover, the study reports that Atazanavir is the most effective chemical compound with $\mathrm{K}_{\mathrm{d}}$ of $94.94 \mathrm{nM}$, followed by Remdesivir (113.13 nM), Efavirenz (199.17 nM), Ritonavir (204.05 nM), and Dolutegravir (336.91 nM) against the SARS-CoV-2 3C-like proteinase. Computational drug repositioning AI models provide a fast and cost-effective way to identify promising repositioning opportunities, and expedited approval procedures [152,156].

\section{Viral Genome Sequencing}

Genome sequencing of various viruses is performed to identify regions of similarity that may have consequences for functional, structural, and evolutionary relationships [157]. Owing to the heavy computational requirements of traditional alignment-based methods, alignment-free genome comparison methods are gaining popularity $[157,158]$. A case study by Randhawa et al [84] proposed an ML-based alignment-free approach for an ultra-fast, inexpensive, and taxonomic classification of whole virus genomes for SARS-CoV-2 that can be used for classification of COVID-19 pathogens in real time.

\section{AI Techniques for FCR}

\section{Ongoing FCR Initiatives}

To combat the ongoing COVID-19 crisis, global scientific collaborations have been encouraged and are necessary now more than ever. Several initiatives are underway to build centralized repositories to share COVID-19-related research [159]. Such global repositories facilitate the understanding of disease characteristics, interventions, and potential mental health impacts on the general population.

\section{Collaborative Open Source Repository}

Peng et al [66] focused on creating a repository of COVID-19 chest X-ray (CXR) and chest CT images. The repository, COVID-19-CT-CXR, is publicly available and contains 1327 CT and 263 X-ray images (as of May 9, 2020) that are inadequately labeled. The authors build a pipeline to automatically extract images from the biomedical literature 
relevant to COVID-19 using a DL model. A recent effort by the National Center for Advancing Translational Sciences to build a centralized, national data repository on COVID-19, called National COVID Cohort Collaborative (N3C), is underway [160]. N3C will support collection and analyses of clinical, laboratory, and diagnostic data from hospitals and health care plans. $\mathrm{N} 3 \mathrm{C}$ along with imaging repositories such as COVID-19-CT-CXR will accelerate clinical and translational research.

\section{Psychological Impact of the COVID-19 Pandemic}

COVID-19 lockdown and home-confinement restrictions have adverse effects on the mental well-being of the general population and specifically high-risk groups, including health care workers, children, and older adults [161]. Several studies have been conducted to understand and respond to these public health emergencies. For instance, Li et al [63] conducted a study using a ML model (support vector machine) and sentiment analysis to explore the effects of COVID-19 on people's mental health and to assist policymakers in developing actionable policies that could aid clinical practitioners. Weibo posts were collected before and after the declaration of the pandemic to build emotional score and cognitive indicators. Key findings of the study reveal that after the declaration of the COVID-19 outbreak in China, there has been a significant impact resulting in increased negative emotions (eg, anxiety and depression) and sensitivity to social risks, and decreased happiness and satisfaction of life. Raamkumar et al [18] used the health belief model (HBM) [162] to determine public perception of physical distancing posts from multiple public health authorities. They used a DL (a variant of recurrent neural network) text classification model to classify Facebook comments related to physical distancing posts into $4 \mathrm{HBM}$ constructs: perceived severity, perceived susceptibility, perceived barriers, and perceived benefits, with accuracy of the model ranging from 0.91 to 0.95 . Moreover, recent developments in the field of NLP, bidirectional encoder representations from transformers [163], XLNet [164], and other hybrid ML models have shown promising results in the field of sentiment analysis. Future studies should focus on these advanced techniques for improved social media content analysis.

\section{AI Techniques for CDT}

\section{Models for Prediction of COVID-19 Cases}

During the initial days of the COVID-19 spread, most research was focused on building mathematical models for estimating the transmission dynamics and prediction of COVID-19 developments $\quad[165,166]$ Specifically, susceptible-exposed-infectious-recovered (SEIR) and auto-regressive integrated moving average (ARIMA) models and their extensions were widely adopted for the projection of COVID-19 cases [167]. These models provided health care and government officials with optimal intervention strategies and control measures to combat the pandemic [167]. A similar suggestion was made by Lalmuanawma et al [12].

\section{Forecasting of COVID-19}

In our systematic review, Yang et al [59] and Moftakhar et al [44] used DL models to fit both statistical models SEIR and
ARIMA. The long-short term memory model proposed by Yang et al [59] and artificial neural network model proposed by Moftakhar et al [44] had a good fit to SEIR and ARIMA, respectively. However, projections of both these mathematical models had deviations less than the $\pm 15 \%$ range of the reported data [167]. Therefore, we recommend future studies should try to fit AI techniques on both the SEIR and ARIMA models to reduce the projection error rate and be better prepared for the second wave of COVID-19.

\section{Impact of Policies on COVID-19 Trajectories}

The accuracy of COVID-19 trajectory projections depends on varying containment policies enforced by different countries $[167,168]$. The study by Yang et al [59] used a DL technique to predict COVID-19 epidemic peaks and sizes with respect to the containment polices. Their study revealed that the continual enforcement of quarantine restrictions, early detection, and subsequent isolation were the most effective in containment of the disease. Relaxing these policies would likely increase the spread of disease by 3-fold for a 5-day delay in implementation and could cause a second peak. We suggest government officials should strictly enforce such policies to prevent a second outbreak of COVID-19.

\section{Theme 2: EDD models}

\section{Current State of COVID-19 Diagnosis}

Many countries ramped up the production of real-time reverse transcription polymerase chain reaction (RT-PCR) testing kits to diagnose COVID-19, and thus far, it remains the gold standard for confirmed diagnosis [169]. However, this laboratory-based test is limited by low sensitivity, as reported by several studies $[169,170]$. As highlighted by both Vaishya et al [20] and Lalmuanawma et al [12], AI can prove helpful in the diagnosis of various infectious diseases (eg, SARS, HIV, and Ebola) when used in conjunction with medical imaging technologies such as CT, magnetic resonance imaging (MRI), and X-ray. Radiological images (CT and X-ray) have been used by clinicians to confirm COVID-19-positive cases; these imaging findings also serve as an important complement to the RT-PCR test [171]. In this systematic review, we found LUS has been used to diagnose COVID-19, in addition to CT and $\mathrm{X}$-Ray. However, we did not find any study using MRI for COVID-19 diagnosis.

\section{Diagnostic Models Based on CT and X-Ray}

Several studies have reported that the use of chest CT for early-stage detection of COVID-19 has proven to have a low rate of misdiagnosis and can provide accurate results even in some asymptomatic cases [172]. We identified 15 studies that used CT to detect COVID-19. One of the most cited studies by Li et al [120] applied DL (COVNet) to differentiate COVID-19 and non-COVID-19 pneumonia CT scans. The area under the receiver operating characteristic (AUROC) curve reported to identify COVID-19 based on chest CT exam was 0.96 and the AUROC curve reported to identify community-acquired pneumonia based on chest CT exam was 0.95. The accuracy reported is slightly higher than that reported by Ardakani et al [93], which was also found in the review by Lalmuanawma et al [12]. However, there are some disadvantages associated with 
using chest CT for COVID-19 diagnosis, such as the high radiation dose ( $7 \mathrm{mSv}$ vs $0.1 \mathrm{mSv}$ for chest $\mathrm{X}$-ray) and the fact that chest $\mathrm{CT}$ is more expensive than chest X-ray [173,174].

In this systematic review, we identified 23 studies that used chest X-ray and applied AI techniques to diagnose COVID-19 cases. A study by Apostolopoulos et al [91] applied a transfer learning strategy to train convolutional neural network models and then automated the detection of COVID-19 using chest X-ray images. The model (VGG19) achieved an overall accuracy of $97.82 \%$ to detect COVID-19 based on a dataset of 224 COVID-19, 700 pneumonia, and 504 normal X-ray images. A similar study was performed by Khan et al [117] using transfer learning and convolutional neural network (Xception) architecture with 71 layers that were trained on the ImageNet dataset. Their model (CoroNet) achieved an average accuracy of $87 \%$ to detect COVID-19 based on a dataset of 284 COVID-19, 657 pneumonia (both viral and bacterial), and 310 normal chest X-ray images. These recently published studies successfully used transfer learning strategy to overcome sample size limitation and adapt generalizability; it is noteworthy that such studies were not available in the earlier literature reviews $[12,20]$. Although chest X-ray is cost-effective and involves a considerably lower radiation dose than chest CT, it is less sensitive, especially in the early stages of the infection and in cases of mild disease [175]. We recommend that new studies develop AI models that can detect COVID-19 by using a combination of CT and X-ray images along with clinical variables to aid clinical practitioners with accurate diagnosis.

\section{Diagnostic Models Based on LUS and Clinical Variables}

During the 2009 influenza (H1N1) epidemic, LUS proved useful in accurately differentiating viral and bacterial pneumonia and were found to have higher sensitivity in detecting avian influenza (H7N9) than chest X-ray [176]. Although clinicians recommend the use of LUS imaging in the emergency room for the diagnosis and management of COVID-19, its role is still unclear [177]. In our review, we identified a study by Roy et al [128] that used a DL model based on an annotated LUS COVID-19 dataset to predict disease severity. The results of the study were reported to be "satisfactory." Moreover, a study by Joshi et al [115] proposed an ML approach that utilizes only complete blood count and gender information of the patient to predict COVID-19 positivity, as an alternative to the RT-PCR test. These authors built a logistic regression model based on retrospective data collected from a single institute and validated using multi-institute data. Prediction of COVID-19 infection demonstrated a C-statistic of $78 \%$ and sensitivity of $93 \%$. The aim of the study was to develop a decision support tool that integrates readily available laboratory test results from patients' EHRs.

\section{Theme 3: DP Models}

\section{Current State of Predicting COVID-19 Progression}

The COVID-19 pandemic has strained global health care systems, especially ICUs, due to the high ICU transfer rates of hospitalized patients with COVID-19 [135]. As the pandemic progressed, the research focus shifted from detecting the presence of the novel coronavirus in patient samples to the prediction of patient recovery and associated risks [178]. Therefore, early systematic reviews included very few studies that focused on DP $[12,20]$. In this review, we found 19 studies that predicted DP and the likely outcomes in the confirmed COVID-19 population. Prior identification of hospitalized patients who may be at high-risk may aid health care providers to more efficiently plan and prepare for ICU resources (eg, beds, ventilators, and staff) [179].

\section{Hospital Resource Management}

A study by Cheng et al [135] developed an ML-based model to predict ICU transfers within 24 hours of hospital admission. The random forest model was used for COVID-19 prediction and was based on multiple variables such as vital signs, nursing assessment, laboratory test results, and electrocardiograms collected during the patient's hospital stay. The overall AUROC curve of the model was reported to be $79.9 \%$. Similar work was done by Shashikumar et al [141] to predict the need for ventilation in hospitalized patients 24 hours in advance. The prediction was not only limited to patients with COVID-19 but also included other hospitalized patients. These authors studied 40 clinical variables, including 6 demographic and 34 dynamic variables (eg, laboratory results, vital signs, sequential organ failure assessment, comorbidity, and length of hospital stay). In contrast to the traditional ML model used by Cheng et al [135], Shashikumar et al [141] resorted to a DL model (VentNet) for prediction with an area under the curve (AUC) of 0.882 for the general ICU population and 0.918 for patients with COVID-19. Both the aforementioned studies relied on clinical variables for prediction, whereas a study by Burian et al [132] combined clinical and imaging parameters for estimating the need for ICU treatment. The major finding of the study was that the patients needing ICU transfers had significantly elevated interleukin-6, C-reactive protein, and leukocyte counts and significantly decreased lymphocyte counts. All studies in this category applied AI techniques to facilitate the efficient use of clinical resources and help hospitals plan their flow of operations to fight the ongoing pandemic.

\section{Risk Stratification}

Prediction and risk stratification of COVID-19 cases that are likely to have adverse outcomes will help to streamline health care resources for patients that need urgent care. In our review, Yadaw et al [146] evaluated different ML models to classify COVID-19 cases as deceased or alive classes. This classification was based on 5 features: age, minimum oxygen saturation during the encounter, type of patient encounter, hydroxychloroquine use, and maximum body temperature. Their study revealed that age and minimum oxygen saturation during encounters were the most predictive features among the different models examined. The overall AUC was reported as 0.91. On the other hand, Ji et al [137] focused on the early identification of COVID-19 cases that are likely to be at high-risk. Variables used for this prediction model included demographics, comorbidities, and laboratory test results. They found a strong correlation between comorbidities and DP as supported by various other studies. The study further suggests that a decrease in lymphocyte count and an increase in lactate dehydrogenase levels are related to DP. The overall AUC reported was 0.759 . 
In both studies, Yadaw et al [146] and Ji et al [137], the ML models were trained on the retrospective data and validated on prospective data. Li et al [139] built a pulmonary disease severity score using X-rays and neural network models. The score was computed as the Euclidean distance between the patient's image and a pool of normal images using the Siamese neural network. The score predicted (AUROC 0.80) subsequent intubation or death within 3 days of hospital admission for patients that were initially not intubated.

COVID-19 pneumonia is associated with high morbidity and mortality, and it is critical to differentiate COVID-19 from general pneumonia [180]. In the study by Jiang et al [138], their model used demographics, vital signs, comorbidities, and laboratory test results to predict patients that are likely to develop ARDS. Of these variables, laboratory levels of alanine aminotransferase (ALT), the presence of myalgias, and elevated hemoglobin were found to be the most predictive features. The overall accuracy of predicting ARDS was $80 \%$. Moreover, using ALT alone, the model achieved an accuracy of $70 \%$. Zhang et al [147] built a DL diagnostic and prognostic predictive model to detect COVID-19 and identified variables associated with risk factors for early intervention and monitoring of the disease. The study comprised 3777 patients (5468 CT scans) to differentiate COVID-19 pneumonia from other types of pneumonia and normal controls. The AUROC of the model was reported as 0.97 .

\section{Distributed AI Architecture and Transfer Learning}

The emergence of COVID-19 has encouraged public health agencies and scientific communities to share data and code, either by building data repositories or adopting federated AI models $[13,181]$. Moreover, transfer learning was adopted to fast-track AI model development, especially using imaging data.

\section{Distributed AI Architecture}

In general, DL techniques are employed to improve prediction accuracy by training models on large volumes of data [182]. In our review, several studies applied AI techniques, either using smaller imaging datasets specific to the organization, or midto large-sized datasets from publicly available repositories. However, there are substantial costs associated with the development and maintenance of such repositories [183]. To overcome data size and cost limitations, Xu et al [110] proposed a decentralized AI architecture to build a generalizable model that is distributed and trained on in-house client datasets, eliminating the need for sharing sensitive clinical data. The proposed framework is in the early phase of adoption and needs technical improvements before it is widely employed by participating health care organizations.

\section{Transfer Learning}

There are classification challenges associated with the diagnosis of COVID-19 using patients' radiological imaging data, which consists of multiple steps. In general, the initial steps involved in image classification are preprocessing, annotation, and feature extraction. Annotation of radiological images is time-consuming and depends on the sheer expense of the expert radiologist. Several strategies have been proposed to address this challenge, such as self-supervised and transfer learning techniques. Our review identified a study by Wang et al [145] that used a transfer learning strategy to aid COVID-19 diagnostic and prognostic analyses. The study used a 2-step transfer learning strategy: first, the model was trained on a large lung cancer CT dataset $(n=4106)$ along with epidermal growth factor receptor gene sequencing to learn associations between chest CT image and micro-level lung functional abnormalities. Thereafter, the model was trained and validated to differentiate COVID-19 from other pneumonia (AUC 0.87-0.88) and viral pneumonia (AUC 0.86) types. We believe such techniques will significantly improve the computational costs associated with training the models.

\section{Summary Points and Recommendations}

The aim of this study was to perform a comprehensive literature review on the role of AI to tackle the current COVID-19 pandemic. The scope of our study was not restricted to a specific application, but to cover all possible areas used by AI-based approaches. The major findings from various COVID-19 studies and the recommendations for future research provided therein are enlisted below.

- $\quad$ RT-PCR remains the gold standard confirmatory test for COVID-19. However, this laboratory test has low sensitivity; therefore, future models should combine radiological images (eg, CT and X-ray), clinical manifestations, and laboratory test results for better accuracy.

- AI model performance might be biased due to lack of adequate sample size from small-scale studies. We suggest that newer studies should utilize data from national and international collaborative COVID-19 repositories. In addition, decentralized AI architecture should be adopted to eliminate the need for sharing sensitive clinical data.

- Most studies included at least some of the effective clinical variables for the prediction of COVID-19 progression. We have provided a comprehensive list of the variables used in the different studies and the best performing models reported therein. A detailed analysis of these variables should be performed to identify variables that are corelated with COVID-19 progression. Such variables should also be considered for future predictive models.

- Few studies have conducted a sentiment analysis using social media content and reported specific negative impacts on people's mental health conditions due to the COVID-19 lockdown. Recent advancements in NLP techniques, such as transformers-based models and hybrid models, have been rarely used for sentiment analysis. We recommend that newer studies employ these advancements for improved analyses.

- Majority of the studies rarely provided details on how the AI model predictions were interpreted. Interpretable AI models allow end users to understand and improve model performance. Users can accept or decline the recommendations when such models are used as a clinical decision support tool.

\section{Limitations}

This review has some inherent limitations. First, there is a possibility of studies missed due to the search methodology used. Second, we excluded 5 publications for which the full 
texts were not available, and this may have introduced bias. Third, we included studies that were available as preprints. Finally, a comparison of AI model performance was not possible in the quantitative descriptive analysis, as variables, sample size, and data sources varied across the selected studies. This systematic review includes publications that were available online as of June 27, 2020. As the COVID-19 pandemic progresses, we intend to perform another review on the studies published after the aforementioned date.

\section{Conclusions}

In this systematic review, we assembled the current COVID-19 literature that utilized AI methods in the area of applications ranging from tracking, containing, and treating viral infection. Our study provides insights on the prospects of AI on the 3 identified COVID-19 themes-CE, EDD, and DP-highlighting the important variables, data types, and available COVID-19 resources that can assist in facilitating clinical and translational research. Our study sheds light on AI applications as a potential drug discovery and risk stratification tool. In addition, our analysis suggested that AI-based diagnostic tools are highly accurate in detecting the presence of the SARS-CoV-2 by using radiological imaging data and can be employed as a decision support tool.

\section{Acknowledgments}

This study was supported in part by the Translational Research Institute (TRI), grant UL1 TR003107 received from the National Center for Advancing Translational Sciences of the National Institutes of Health (NIH). The content of this manuscript is solely the responsibility of the authors and does not necessarily represent the official views of the NIH.

\section{Conflicts of Interest}

KS has intellectual property on signal processing of peripheral venous pressure waveforms. The conflict is unrelated to the material presented in this article.

\section{Multimedia Appendix 1}

Query syntax for study search in all 3 databases (PubMed, CINAHL, and Web of Science).

[DOCX File, 12 KB-Multimedia Appendix 1]

\section{Multimedia Appendix 2}

Details of 71 studies qualified under the Computational Epidemiology (CE) theme.

[DOCX File, 97 KB-Multimedia Appendix 2]

\section{Multimedia Appendix 3}

Details of 40 studies qualified under the Early Detection and Diagnosis (EDD) theme.

[DOCX File , 69 KB-Multimedia Appendix 3]

\section{Multimedia Appendix 4}

Details of 19 studies qualified under the Disease Progression (DP) theme.

[DOCX File , 47 KB-Multimedia Appendix 4]

\section{References}

1. Dong E, Du H, Gardner L. An interactive web-based dashboard to track COVID-19 in real time. Lancet Infect Dis 2020 May;20(5):533-534 [FREE Full text] [doi: 10.1016/S1473-3099(20)30120-1] [Medline: 32087114]

2. Sedik A, Iliyasu A, Abd El-Rahiem B, Abdel Samea ME, Abdel-Raheem A, Hammad M, et al. Deploying machine and deep learning models for efficient data-augmented detection of COVID-19 infections. Viruses 2020 Jul 16;12(7) [FREE Full text] [doi: 10.3390/v12070769] [Medline: $\underline{32708803]}$

3. Singhal T. A review of Coronavirus Disease-2019 (COVID-19). Indian J Pediatr 2020 Apr;87(4):281-286 [FREE Full text] [doi: 10.1007/s12098-020-03263-6] [Medline: 32166607]

4. Ozder A. A novel indicator predicts 2019 novel coronavirus infection in subjects with diabetes. Diabetes Res Clin Pract 2020 Aug;166:108294 [FREE Full text] [doi: 10.1016/j.diabres.2020.108294] [Medline: 32623037]

5. Soltani J, Sedighi I, Shalchi Z, Sami G, Moradveisi B, Nahidi S. Pediatric coronavirus disease 2019 (COVID-19): An insight from west of Iran. North Clin Istanb 2020;7(3):284-291 [FREE Full text] [doi: 10.14744/nci.2020.90277] [Medline: 32478302]

6. Cyranoski D. 'We need to be alert': Scientists fear second coronavirus wave as China's lockdowns ease. Nature. 2020 Mar 30. URL: https://www.nature.com/articles/d41586-020-00938-0 [accessed 2020-12-30] 
7. Mahmud I, Al-Mohaimeed A. COVID-19: Utilizing local experience to suggest optimal global strategies to prevent and control the pandemic. Int J Health Sci 2020 May;14(3):1-3 [FREE Full text] [Medline: $\underline{32536840}$ ]

8. Leung K, Wu JT, Liu D, Leung GM. First-wave COVID-19 transmissibility and severity in China outside Hubei after control measures, and second-wave scenario planning: a modelling impact assessment. Lancet $2020 \mathrm{Apr}$ 25;395(10233):1382-1393 [FREE Full text] [doi: 10.1016/S0140-6736(20)30746-7] [Medline: $\underline{32277878]}$

9. Ali I. COVID-19: Are we ready for the second wave? Disaster Med Public Health Prep 2020 Oct;14(5):e16-e18 [FREE Full text] [doi: 10.1017/dmp.2020.149] [Medline: 32379015]

10. Xu S, Li Y. Beware of the second wave of COVID-19. Lancet 2020 Apr 25;395(10233):1321-1322 [FREE Full text] [doi:

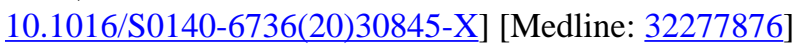

11. Panch T, Szolovits P, Atun R. Artificial intelligence, machine learning and health systems. J Glob Health 2018 Dec;8(2):020303 [FREE Full text] [doi: 10.7189/jogh.08.020303] [Medline: 30405904]

12. Lalmuanawma S, Hussain J, Chhakchhuak L. Applications of machine learning and artificial intelligence for Covid-19 (SARS-CoV-2) pandemic: A review. Chaos Solitons Fractals 2020 Oct;139:110059 [FREE Full text] [doi: 10.1016/j.chaos.2020.110059] [Medline: 32834612]

13. Wynants L, Van Calster B, Collins GS, Riley RD, Heinze G, Schuit E, et al. Prediction models for diagnosis and prognosis of covid-19 infection: systematic review and critical appraisal. BMJ 2020 Apr 07;369:m1328 [FREE Full text] [doi: 10.1136/bmj.m1328] [Medline: $\underline{32265220]}$

14. Sear RF, Velasquez N, Leahy R, Restrepo NJ, Oud SE, Gabriel N, et al. Quantifying COVID-19 content in the online health opinion war using machine learning. IEEE Access 2020;8:91886-91893. [doi: 10.1109/access.2020.2993967]

15. Ye J. The role of health technology and informatics in a global public health emergency: practices and implications from the COVID-19 pandemic. JMIR Med Inform 2020 Jul 14;8(7):e19866 [FREE Full text] [doi: 10.2196/19866] [Medline: $\underline{32568725]}$

16. Beck BR, Shin B, Choi Y, Park S, Kang K. Predicting commercially available antiviral drugs that may act on the novel coronavirus (SARS-CoV-2) through a drug-target interaction deep learning model. Comput Struct Biotechnol J 2020;18:784-790 [FREE Full text] [doi: 10.1016/j.csbj.2020.03.025] [Medline: 32280433]

17. Fu L, Li Y, Cheng A, Pang P, Shu Z. a novel machine learning-derived radiomic signature of the whole lung differentiates stable from progressive COVID-19 infection: a retrospective cohort study. J Thorac Imaging 2020 Jun 16 [FREE Full text] [doi: 10.1097/RTI.0000000000000544] [Medline: $\underline{\text { 32555006] }}$

18. Sesagiri Raamkumar A, Tan SG, Wee HL. Use of health belief model-based deep learning classifiers for COVID-19 social media content to examine public perceptions of physical distancing: model development and case study. JMIR Public Health Surveill 2020 Jul 14;6(3):e20493 [FREE Full text] [doi: 10.2196/20493] [Medline: 32540840]

19. Syed S, Baghal A, Prior F, Zozus M, Al-Shukri S, Syeda HB, et al. Toolkit to compute time-based Elixhauser comorbidity indices and extension to common data models. Healthc Inform Res 2020 Jul;26(3):193-200 [FREE Full text] [doi: 10.4258/hir.2020.26.3.193] [Medline: 32819037]

20. Vaishya R, Javaid M, Khan IH, Haleem A. Artificial intelligence (AI) applications for COVID-19 pandemic. Diabetes Metab Syndr 2020;14(4):337-339 [FREE Full text] [doi: 10.1016/j.dsx.2020.04.012] [Medline: 32305024]

21. Shi F, Wang J, Shi J, Wu Z, Wang Q, Tang Z, et al. Review of artificial intelligence techniques in imaging data acquisition, segmentation and diagnosis for COVID-19. IEEE Rev Biomed Eng 2020 Apr 16;PP. [doi: 10.1109/RBME.2020.2987975] [Medline: 32305937]

22. Liberati A, Altman DG, Tetzlaff J, Mulrow C, Gøtzsche PC, Ioannidis JPA, et al. The PRISMA statement for reporting systematic reviews and meta-analyses of studies that evaluate healthcare interventions: explanation and elaboration. BMJ 2009 Jul 21;339:b2700 [FREE Full text] [doi: 10.1136/bmj.b2700] [Medline: 19622552]

23. Arora P, Kumar H, Panigrahi BK. Prediction and analysis of COVID-19 positive cases using deep learning models: A descriptive case study of India. Chaos Solitons Fractals 2020 Oct;139:110017 [FREE Full text] [doi: 10.1016/j.chaos.2020.110017] [Medline: $\underline{32572310]}$

24. Ayyoubzadeh SM, Ayyoubzadeh SM, Zahedi H, Ahmadi M, R Niakan Kalhori S. Predicting COVID-19 incidence through analysis of google trends data in Iran: data mining and deep learning pilot study. JMIR Public Health Surveill 2020 Apr 14;6(2):e18828 [FREE Full text] [doi: 10.2196/18828] [Medline: 32234709]

25. Car Z, Baressi Šegota S, Anđelić N, Lorencin I, Mrzljak V. Modeling the spread of COVID-19 infection using a multilayer perceptron. Comput Math Methods Med 2020;2020:5714714 [FREE Full text] [doi: 10.1155/2020/5714714] [Medline: 32565882]

26. Carrillo-Larco RM, Castillo-Cara M. Using country-level variables to classify countries according to the number of confirmed COVID-19 cases: An unsupervised machine learning approach. Wellcome Open Res 2020;5:56 [FREE Full text] [doi: 10.12688/wellcomeopenres. 15819.3] [Medline: $\underline{\text { 32587900] }}$

27. Chatterjee A, Gerdes MW, Martinez SG. Statistical explorations and univariate timeseries analysis on COVID-19 datasets to understand the trend of disease spreading and death. Sensors (Basel) 2020 May 29;20(11) [FREE Full text] [doi: 10.3390/s20113089] [Medline: 32486055]

28. Chimmula VKR, Zhang L. Time series forecasting of COVID-19 transmission in Canada using LSTM networks. Chaos Solitons Fractals 2020 Jun;135:109864 [FREE Full text] [doi: 10.1016/j.chaos.2020.109864] [Medline: $\underline{\text { 32390691] }}$ 
29. Chowdhury R, Heng K, Shawon MSR, Goh G, Okonofua D, Ochoa-Rosales C, Global Dynamic Interventions Strategies for COVID-19 Collaborative Group. Dynamic interventions to control COVID-19 pandemic: a multivariate prediction modelling study comparing 16 worldwide countries. Eur J Epidemiol 2020 May;35(5):389-399 [FREE Full text] [doi: 10.1007/s10654-020-00649-w] [Medline: 32430840]

30. Cobb JS, Seale MA. Examining the effect of social distancing on the compound growth rate of COVID-19 at the county level (United States) using statistical analyses and a random forest machine learning model. Public Health 2020 Aug;185:27-29 [FREE Full text] [doi: 10.1016/j.puhe.2020.04.016] [Medline: 32526559]

31. Delen D, Eryarsoy E, Davazdahemami B. No place like home: cross-national data analysis of the efficacy of social distancing during the COVID-19 pandemic. JMIR Public Health Surveill 2020 May 28;6(2):e19862 [FREE Full text] [doi: 10.2196/19862] [Medline: 32434145]

32. Fong SJ, Li G, Dey N, Gonzalez-Crespo R, Herrera-Viedma E. Finding an accurate early forecasting model from small dataset: a case of 2019-nCoV novel coronavirus outbreak. IJIMAI 2020;6(1):132. [doi: 10.9781/ijimai.2020.02.002]

33. Fong SJ, Li G, Dey N, Crespo RG, Herrera-Viedma E. Composite Monte Carlo decision making under high uncertainty of novel coronavirus epidemic using hybridized deep learning and fuzzy rule induction. Appl Soft Comput 2020 Aug;93:106282 [FREE Full text] [doi: 10.1016/j.asoc.2020.106282] [Medline: $\underline{32362799]}$

34. Fronza R, Lusic M, Schmidt M, Lucic B. Spatial-temporal variations in atmospheric factors contribute to SARS-CoV-2 outbreak. Viruses 2020 May 27;12(6). [doi: 10.3390/v12060588] [Medline: 32471302]

35. Golder S, Klein A, Magge A, O'Connor K, Cai H, Weissenbacher D. Extending a chronological and geographical analysis of personal reports of COVID-19 on Twitter to England, UK. medRxiv 2020 May 08 [FREE Full text] [doi: 10.1101/2020.05.05.20083436] [Medline: $\underline{32511492]}$

36. Shaffiee Haghshenas S, Pirouz B, Shaffiee Haghshenas S, Pirouz B, Piro P, Na K, et al. Prioritizing and analyzing the role of climate and urban parameters in the confirmed cases of COVID-19 based on artificial intelligence applications. Int J Environ Res Public Health 2020 May 25;17(10) [FREE Full text] [doi: 10.3390/ijerph17103730] [Medline: 32466199]

37. Kırbaş I, Sözen A, Tuncer AD, Kazancıoğlu FS. Comparative analysis and forecasting of COVID-19 cases in various European countries with ARIMA, NARNN and LSTM approaches. Chaos Solitons Fractals 2020 Sep;138:110015 [FREE Full text] [doi: 10.1016/j.chaos.2020.110015] [Medline: $\underline{\text { 32565625] }}$

38. Klein A, Magge A, O'Connor K, Cai H, Weissenbacher D, Gonzalez-Hernandez G. A chronological and geographical analysis of personal reports of COVID-19 on Twitter. medRxiv 2020 Preprint posted online on April 24. [FREE Full text] [doi: 10.1101/2020.04.19.20069948] [Medline: 32511608]

39. Liu D, Clemente L, Poirier C, Ding X, Chinazzi M, Davis JT, et al. A machine learning methodology for real-time forecasting of the 2019-2020 COVID-19 outbreak using Internet searches, news alerts, and estimates from mechanistic models. arXiv 2020 Preprint posted online April 8. [Medline: $\underline{32550248]}$

40. Liu Z, Huang S, Lu W, Su Z, Yin X, Liang H, et al. Modeling the trend of coronavirus disease 2019 and restoration of operational capability of metropolitan medical service in China: a machine learning and mathematical model-based analysis. Glob Health Res Policy 2020;5:20 [FREE Full text] [doi: 10.1186/s41256-020-00145-4] [Medline: $\underline{\text { 32391439] }}$

41. Mackey T, Purushothaman V, Li J, Shah N, Nali M, Bardier C, et al. Machine learning to detect self-reporting of symptoms, testing access, and recovery associated with COVID-19 on twitter: retrospective big data infoveillance study. JMIR Public Health Surveill 2020 Jun 08;6(2):e19509 [FREE Full text] [doi: 10.2196/19509] [Medline: $\underline{\text { 32490846] }}$

42. Melin P, Monica JC, Sanchez D, Castillo O. Analysis of spatial spread relationships of coronavirus (COVID-19) pandemic in the world using self organizing maps. Chaos Solitons Fractals 2020 Sep;138:109917 [FREE Full text] [doi: 10.1016/j.chaos.2020.109917] [Medline: $\underline{\text { 32501376] }}$

43. Melin P, Monica JC, Sanchez D, Castillo O. Multiple ensemble neural network models with fuzzy response aggregation for predicting COVID-19 time series: the case of Mexico. Healthcare (Basel) 2020 Jun 19;8(2) [FREE Full text] [doi: 10.3390/healthcare8020181] [Medline: 32575622]

44. Moftakhar L, Seif M, Safe MS. Exponentially increasing trend of infected patients with COVID-19 in Iran: a comparison of neural network and ARIMA forecasting models. Iran J Public Health 2020 Jul 11. [doi: 10.18502/ijph.v49is1.3675]

45. Mollalo A, Rivera KM, Vahedi B. Artificial neural network modeling of novel coronavirus (COVID-19) incidence rates across the continental United States. Int J Environ Res Public Health 2020 Jun 12;17(12) [FREE Full text] [doi: 10.3390/ijerph17124204] [Medline: 32545581]

46. Pirouz B, Shaffiee Haghshenas S, Shaffiee Haghshenas S, Piro P. Investigating a serious challenge in the sustainable development process: analysis of confirmed cases of COVID-19 (new type of coronavirus) through a binary classification using artificial intelligence and regression analysis. Sustainability 2020 Mar 20;12(6):2427. [doi: 10.3390/su12062427]

47. Pourghasemi HR, Pouyan S, Heidari B, Farajzadeh Z, Fallah Shamsi SR, Babaei S, et al. Spatial modeling, risk mapping, change detection, and outbreak trend analysis of coronavirus (COVID-19) in Iran (days between February 19 and June 14, 2020). Int J Infect Dis 2020 Sep;98:90-108 [FREE Full text] [doi: 10.1016/j.ijid.2020.06.058] [Medline: 32574693]

48. Qiu Y, Chen X, Shi W. Impacts of social and economic factors on the transmission of coronavirus disease 2019 (COVID-19) in China. medRxiv. 2020 Preprint posted online on March 17. [FREE Full text] [doi: 10.1101/2020.03.13.20035238] [Medline: 32511444] 
49. Rao JS, Zhang H, Mantero A. Contextualizing covid-19 spread: a county level analysis, urban versus rural, and implications for preparing for the next wave. medRxiv. 2020 Preprint posted online on April 29. [FREE Full text] [doi: 10.1101/2020.04.24.20078204] [Medline: $\underline{\text { 32511653] }}$

50. Ribeiro MHDM, da Silva RG, Mariani VC, Coelho LDS. Short-term forecasting COVID-19 cumulative confirmed cases: Perspectives for Brazil. Chaos Solitons Fractals 2020 Jun;135:109853 [FREE Full text] [doi: 10.1016/j.chaos.2020.109853] [Medline: 32501370]

51. Saba AI, Elsheikh AH. Forecasting the prevalence of COVID-19 outbreak in Egypt using nonlinear autoregressive artificial neural networks. Process Saf Environ Prot 2020 Sep;141:1-8 [FREE Full text] [doi: 10.1016/j.psep.2020.05.029] [Medline: 32501368]

52. Shen C, Chen A, Luo C, Zhang J, Feng B, Liao W. Using reports of symptoms and diagnoses on social media to predict COVID-19 case counts in mainland china: observational infoveillance study. J Med Internet Res 2020 May 28;22(5):e19421 [FREE Full text] [doi: 10.2196/19421] [Medline: 32452804]

53. Simsek M, Kantarci B. Artificial intelligence-empowered mobilization of assessments in COVID-19-like pandemics: a case study for early flattening of the curve. Int J Environ Res Public Health 2020 May 14;17(10) [FREE Full text] [doi: 10.3390/ijerph17103437] [Medline: $\underline{\text { 32423150] }}$

54. Sujath R, Chatterjee JM, Hassanien AE. A machine learning forecasting model for COVID-19 pandemic in India. Stoch Environ Res Risk Assess 2020 May 30;34(7):959-972. [doi: 10.1007/s00477-020-01827-8]

55. Tiwari S, Kumar S, Guleria K. Outbreak trends of Coronavirus Disease-2019 in India: a prediction. Disaster Med Public Health Prep 2020 Oct;14(5):e33-e38 [FREE Full text] [doi: 10.1017/dmp.2020.115] [Medline: 32317044]

56. Tomar A, Gupta N. Prediction for the spread of COVID-19 in India and effectiveness of preventive measures. Sci Total Environ 2020 Aug 01;728:138762 [FREE Full text] [doi: 10.1016/j.scitotenv.2020.138762] [Medline: $\underline{32334157]}$

57. Vaid S, McAdie A, Kremer R, Khanduja V, Bhandari M. Risk of a second wave of Covid-19 infections: using artificial intelligence to investigate stringency of physical distancing policies in North America. Int Orthop 2020 Aug;44(8):1581-1589 [FREE Full text] [doi: 10.1007/s00264-020-04653-3] [Medline: 32504213]

58. Wen A, Wang L, He H, Liu S, Fu S, Sohn S, et al. An aberration detection-based approach for sentinel syndromic surveillance of COVID-19 and other novel influenza-like illnesses. medRxiv. 2020 Preprint posted online on June 09. [FREE Full text] [doi: 10.1101/2020.06.08.20124990] [Medline: 32577704]

59. Yang Z, Zeng Z, Wang K, Wong S, Liang W, Zanin M, et al. Modified SEIR and AI prediction of the epidemics trend of COVID-19 in China under public health interventions. J Thorac Dis 2020 Mar;12(3):165-174 [FREE Full text] [doi: 10.21037/jtd.2020.02.64] [Medline: 32274081]

60. Zheng N, Du S, Wang J, Zhang H, Cui W, Kang Z, et al. Predicting COVID-19 in China using hybrid AI model. IEEE Trans. Cybern 2020 Jul;50(7):2891-2904. [doi: 10.1109/tcyb.2020.2990162]

61. Zhou X, Wu Z, Yu R, Cao S, Fang W, Jiang Z, et al. Modelling-based evaluation of the effect of quarantine control by the Chinese government in the coronavirus disease 2019 outbreak. Sci China Life Sci 2020 Aug;63(8):1257-1260 [FREE Full text] [doi: 10.1007/s11427-020-1717-9] [Medline: $\underline{32394245]}$

62. Zhu G, Li J, Meng Z, Yu Y, Li Y, Tang X, et al. Learning from large-scale wearable device data for predicting epidemics trend of COVID-19. Discrete Dynamics in Nature and Society 2020 May 05;2020:1-8. [doi: 10.1155/2020/6152041]

63. Li S, Wang Y, Xue J, Zhao N, Zhu T. The impact of COVID-19 epidemic declaration on psychological consequences: a study on active Weibo users. Int J Environ Res Public Health 2020 Mar 19;17(6) [FREE Full text] [doi: 10.3390/ijerph17062032] [Medline: 32204411]

64. Hosni Mahmoud HA, Mengash HA. A novel technique for automated concealed face detection in surveillance videos. Pers Ubiquitous Comput 2020 Jun 12:1-12 [FREE Full text] [doi: 10.1007/s00779-020-01419-x] [Medline: 32837499]

65. Obeid JS, Davis M, Turner M, Meystre SM, Heider PM, O'Bryan EC, et al. An artificial intelligence approach to COVID-19 infection risk assessment in virtual visits: A case report. J Am Med Inform Assoc 2020 Aug 01;27(8):1321-1325 [FREE Full text] [doi: 10.1093/jamia/ocaa105] [Medline: $\underline{\text { 32449766] }}$

66. Peng Y, Tang Y, Lee S, Zhu Y, Summers RM, Lu Z. COVID-19-CT-CXR: a freely accessible and weakly labeled chest X-ray and CT image collection on COVID-19 from biomedical literature. arXiv. 2020 Preprint posted online Jun 11. [Medline: $\underline{\text { 32550254] }}$

67. Ramalingam B, Yin J, Rajesh Elara M, Tamilselvam YK, Mohan Rayguru M, Muthugala MAVJ, et al. A human support robot for the cleaning and maintenance of door handles using a deep-learning framework. Sensors 2020 Jul 23;20(12) [FREE Full text] [doi: 10.3390/s20123543] [Medline: 32585864]

68. Wahbeh A, Nasralah T, Al-Ramahi M, El-Gayar O. Mining physicians' opinions on social media to obtain insights into COVID-19: mixed methods analysis. JMIR Public Health Surveill 2020 Jun 18;6(2):e19276 [FREE Full text] [doi: 10.2196/19276] [Medline: $\underline{32421686]}$

69. Abdelmageed M, Abdelmoneim A, Mustafa M, Elfadol N, Murshed N, Shantier S, et al. Design of a multiepitope-based peptide vaccine against the e protein of human COVID-19: an immunoinformatics approach. Biomed Res Int 2020 May 11;2020:2683286 [FREE Full text] [doi: 10.1155/2020/2683286] [Medline: 32461973]

70. Saçar Demirci MD, Adan A. Computational analysis of microRNA-mediated interactions in SARS-CoV-2 infection. PeerJ 2020;8:e9369 [FREE Full text] [doi: 10.7717/peerj.9369] [Medline: 32547891] 
71. Gao K, Nguyen DD, Wang R, Wei G. Machine intelligence design of 2019-nCoV drugs. bioRxiv 2020 Mar 04 [FREE Full text] [doi: 10.1101/2020.01.30.927889] [Medline: $\underline{\text { 32511308] }}$

72. Gao K, Nguyen DD, Chen J, Wang R, Wei G. Repositioning of 8565 existing drugs for COVID-19. J Phys Chem Lett 2020 Jul 02;11(13):5373-5382 [FREE Full text] [doi: 10.1021/acs.jpclett.0c01579] [Medline: 32543196]

73. Gussow AB, Auslander N, Faure G, Wolf YI, Zhang F, Koonin EV. Genomic determinants of pathogenicity in SARS-CoV-2 and other human coronaviruses. Proc Natl Acad Sci USA 2020 Jun 30;117(26):15193-15199 [FREE Full text] [doi: 10.1073/pnas.2008176117] [Medline: 32522874]

74. Heo L, Feig M. Modeling of severe acute respiratory syndrome coronavirus 2 (SARS-CoV-2) proteins by machine learning and physics-based refinement. bioRxiv 2020 Mar 28 [FREE Full text] [doi: 10.1101/2020.03.25.008904] [Medline: 32511334]

75. Ke Y, Peng T, Yeh T, Huang W, Chang S, Wu S, et al. Artificial intelligence approach fighting COVID-19 with repurposing drugs. Biomed J 2020 Aug;43(4):355-362 [FREE Full text] [doi: 10.1016/j.bj.2020.05.001] [Medline: 32426387]

76. Kim J, Zhang J, Cha Y, Kolitz S, Funt J, Escalante Chong R, et al. Advanced bioinformatics rapidly identifies existing therapeutics for patients with coronavirus disease-2019 (COVID-19). J Transl Med 2020 Jun 25;18(1):257 [FREE Full text] [doi: 10.1186/s12967-020-02430-9] [Medline: 32586380]

77. Liu G, Carter B, Bricken T, Jain S, Viard M, Carrington M, et al. Robust computational design and evaluation of peptide vaccines for cellular immunity with application to SARS-CoV-2. bioRxiv. 2020 Preprint posted online on May 17. [FREE Full text] [doi: 10.1101/2020.05.16.088989] [Medline: 32511351]

78. Mick E, Kamm J, Pisco AO, Ratnasiri K, Babik JM, Calfee CS, et al. Upper airway gene expression differentiates COVID-19 from other acute respiratory illnesses and reveals suppression of innate immune responses by SARS-CoV-2. medRxiv. 2020 May 19 Preprint posted online on May 22. [FREE Full text] [doi: 10.1101/2020.05.18.20105171] [Medline: $\underline{32511476]}$

79. Mirabelli C, Wotring JW, Zhang CJ, McCarty SM, Fursmidt R, Frum T, et al. Morphological Cell Profiling of SARS-CoV-2 Infection Identifies Drug Repurposing Candidates for COVID-19. bioRxiv. 2020 Preprint posted online on December 7. [FREE Full text] [doi: $\underline{10.1101 / 2020.05 .27 .117184]}$ [Medline: $\underline{32577649}$ ]

80. Nguyen DD, Gao K, Chen J, Wang R, Wei G. Potentially highly potent drugs for 2019-nCoV. bioRxiv. 2020 Preprint posted online on February 13. [FREE Full text] [doi: 10.1101/2020.02.05.936013] [Medline: 32511344]

81. Ong E, Wong MU, Huffman A, He Y. COVID-19 coronavirus vaccine design using reverse vaccinology and machine learning. bioRxiv. 2020 Preprint posted online on March 23. [FREE Full text] [doi: 10.1101/2020.03.20.000141] [Medline: 32511333]

82. Pathan RK, Biswas M, Khandaker MU. Time series prediction of COVID-19 by mutation rate analysis using recurrent neural network-based LSTM model. Chaos Solitons Fractals 2020 Oct;138:110018 [FREE Full text] [doi: 10.1016/j.chaos.2020.110018] [Medline: 32565626]

83. Qiang X, Xu P, Fang G, Liu W, Kou Z. Using the spike protein feature to predict infection risk and monitor the evolutionary dynamic of coronavirus. Infect Dis Poverty 2020 Mar 25;9(1):33 [FREE Full text] [doi: 10.1186/s40249-020-00649-8] [Medline: 32209118]

84. Randhawa G, Soltysiak M, El Roz H, de Souza CPE, Hill K, Kari L. Machine learning using intrinsic genomic signatures for rapid classification of novel pathogens: COVID-19 case study. PLoS One 2020;15(4):e0232391 [FREE Full text] [doi: 10.1371/journal.pone.0232391] [Medline: 32330208]

85. Song Y, Song J, Wei X, Huang M, Sun M, Zhu L, et al. Discovery of aptamers targeting the receptor-binding domain of the SARS-CoV-2 spike glycoprotein. Anal Chem 2020 Jul 21;92(14):9895-9900 [FREE Full text] [doi:

10.1021/acs.analchem.0c01394] [Medline: 32551560]

86. Tang B, He F, Liu D, Fang M, Wu Z, Xu D. AI-aided design of novel targeted covalent inhibitors against SARS-CoV-2. bioRxiv 2020 Mar 08 [FREE Full text] [doi: 10.1101/2020.03.03.972133] [Medline: 32511346]

87. Ton A, Gentile F, Hsing M, Ban F, Cherkasov A. Rapid identification of potential inhibitors of SARS-CoV-2 main protease by deep docking of 1.3 billion compounds. Mol Inform 2020 Aug;39(8):e2000028 [FREE Full text] [doi: 10.1002/minf.202000028] [Medline: $\underline{\text { 32162456] }}$

88. Wu K, Zou J, Chang HY. RNA-GPS predicts SARS-CoV-2 RNA localization to host mitochondria and nucleolus. bioRxiv. 2020 Preprint posted online on April 28. [FREE Full text] [doi: 10.1101/2020.04.28.065201] [Medline: 32511373]

89. Zhang H, Saravanan K, Yang Y, Hossain M, Li J, Ren X, et al. Deep learning based drug screening for novel coronavirus 2019-nCov. Interdiscip Sci 2020 Sep;12(3):368-376 [FREE Full text] [doi: 10.1007/s12539-020-00376-6] [Medline: $\underline{32488835]}$

90. Han X, Wang J, Zhang M, Wang X. Using social media to mine and analyze public opinion related to COVID-19 in China. Int J Environ Res Public Health 2020 Apr 17;17(8) [FREE Full text] [doi: 10.3390/ijerph17082788] [Medline: 32316647]

91. Apostolopoulos ID, Mpesiana TA. Covid-19: automatic detection from X-ray images utilizing transfer learning with convolutional neural networks. Phys Eng Sci Med 2020 Jul;43(2):635-640 [FREE Full text] [doi: 10.1007/s13246-020-00865-4] [Medline: 32524445]

92. Apostolopoulos ID, Aznaouridis SI, Tzani MA. Extracting possibly representative COVID-19 biomarkers from X-ray images with deep learning approach and image data related to pulmonary diseases. J Med Biol Eng 2020 May 14:1-8 [FREE Full text] [doi: 10.1007/s40846-020-00529-4] [Medline: $\underline{32412551]}$ 
93. Ardakani AA, Kanafi AR, Acharya UR, Khadem N, Mohammadi A. Application of deep learning technique to manage COVID-19 in routine clinical practice using CT images: Results of 10 convolutional neural networks. Comput Biol Med 2020 Jun;121:103795 [FREE Full text] [doi: 10.1016/j.compbiomed.2020.103795] [Medline: $\underline{32568676}$ ]

94. Bai HX, Wang R, Xiong Z, Hsieh B, Chang K, Halsey K, et al. Artificial intelligence augmentation of radiologist performance in distinguishing COVID-19 from pneumonia of other origin at chest CT. Radiology 2020 Sep;296(3):E156-E165 [FREE Full text] [doi: 10.1148/radiol.2020201491] [Medline: 32339081]

95. Benbrahim H, Hachimi H, Amine A. Deep transfer learning with apache spark to detect COVID-19 in chest X-ray images. Romanian Journal of Information Science and Technology 2020;23:000537095200010.

96. Chaganti S, Balachandran A, Chabin G, Cohen S, Flohr T, Georgescu B, et al. Quantification of tomographic patterns associated with COVID-19 from chest CT. ArXiv 2020 Apr 02. [Medline: 32550252]

97. Das D, Santosh KC, Pal U. Truncated inception net: COVID-19 outbreak screening using chest X-rays. Phys Eng Sci Med 2020 Oct;43(3):915-925 [FREE Full text] [doi: 10.1007/s13246-020-00888-x] [Medline: 32588200]

98. El Asnaoui K, Chawki Y. Using X-ray images and deep learning for automated detection of coronavirus disease. J Biomol Struct Dyn 2020 May 22:1-12 [FREE Full text] [doi: 10.1080/07391102.2020.1767212] [Medline: $\underline{32397844]}$

99. Singh K, Siddhartha M, Singh A. Diagnosis of Coronavirus Disease (COVID-19) from chest X-ray images using modified XceptionNet. Romanian Journal of Information Science and Technology 2020 Jun;23(657):91-115.

100. Song J, Wang H, Liu Y, Wu W, Dai G, Wu Z, et al. End-to-end automatic differentiation of the coronavirus disease 2019 (COVID-19) from viral pneumonia based on chest CT. Eur J Nucl Med Mol Imaging 2020 Oct;47(11):2516-2524 [FREE Full text] [doi: 10.1007/s00259-020-04929-1] [Medline: 32567006]

101. Toğaçar M, Ergen B, Cömert Z. COVID-19 detection using deep learning models to exploit Social Mimic Optimization and structured chest X-ray images using fuzzy color and stacking approaches. Comput Biol Med 2020 Jun;121:103805 [FREE Full text] [doi: 10.1016/j.compbiomed.2020.103805] [Medline: 32568679]

102. Ozturk T, Talo M, Yildirim EA, Baloglu UB, Yildirim O, Rajendra Acharya U. Automated detection of COVID-19 cases using deep neural networks with X-ray images. Comput Biol Med 2020 Jun;121:103792 [FREE Full text] [doi: 10.1016/j.compbiomed.2020.103792] [Medline: 32568675]

103. Tuncer T, Dogan S, Ozyurt F. An automated residual exemplar local binary pattern and iterative reliefF based COVID-19 detection method using chest X-ray image. Chemometr Intell Lab Syst 2020 Aug 15;203:104054 [FREE Full text] [doi: 10.1016/j.chemolab.2020.104054] [Medline: 32427226]

104. Ucar F, Korkmaz D. COVIDiagnosis-Net: Deep Bayes-SqueezeNet based diagnosis of the coronavirus disease 2019 (COVID-19) from X-ray images. Med Hypotheses 2020 Jul;140:109761 [FREE Full text] [doi: 10.1016/j.mehy.2020.109761] [Medline: 32344309]

105. Vaid S, Kalantar R, Bhandari M. Deep learning COVID-19 detection bias: accuracy through artificial intelligence. Int Orthop 2020 Aug;44(8):1539-1542 [FREE Full text] [doi: 10.1007/s00264-020-04609-7] [Medline: 32462314]

106. Waheed A, Goyal M, Gupta D, Khanna A, Al-Turjman F, Pinheiro PR. CovidGAN: data augmentation using auxiliary classifier GAN for improved Covid-19 detection. IEEE Access 2020;8:91916-91923. [doi: 10.1109/access.2020.2994762]

107. Warman A, Warman P, Sharma A, Parikh P, Warman R, Viswanadhan N, et al. Interpretable artificial intelligence for COVID-19 diagnosis from chest CT reveals specificity of ground-glass opacities. medRxiv. 2020 Preprint posted online on May 22. [FREE Full text] [doi: 10.1101/2020.05.16.20103408] [Medline: 32511545]

108. Wu X, Hui H, Niu M, Li L, Wang L, He B, et al. Deep learning-based multi-view fusion model for screening 2019 novel coronavirus pneumonia: A multicentre study. Eur J Radiol 2020 Jul;128:109041 [FREE Full text] [doi:

10.1016/j.ejrad.2020.109041] [Medline: 32408222]

109. Xie W, Jacobs C, Charbonnier J, van Ginneken B. Relational modeling for robust and efficient pulmonary lobe segmentation in CT scans. ArXiv 2020 May 16. [Medline: 32550251]

110. Xu Y, Ma L, Yang F, Chen Y, Ma K, Yang J, et al. A collaborative online AI engine for CT-based COVID-19 diagnosis. medRxiv 2020 May 19 [FREE Full text] [doi: 10.1101/2020.05.10.20096073] [Medline: $\underline{32511484]}$

111. Yang S, Jiang L, Cao Z, Wang L, Cao J, Feng R, et al. Deep learning for detecting corona virus disease 2019 (COVID-19) on high-resolution computed tomography: a pilot study. Ann Transl Med 2020 Apr;8(7):450 [FREE Full text] [doi: 10.21037/atm.2020.03.132] [Medline: 32395494]

112. Yi PH, Kim TK, Lin CT. Generalizability of deep learning tuberculosis classifier to COVID-19 chest radiographs: new tricks for an old algorithm? J Thorac Imaging 2020 Jul;35(4):W102-W104. [doi: 10.1097/RTI.0000000000000532] [Medline: $\underline{32427650]}$

113. Elaziz MA, Hosny KM, Salah A, Darwish MM, Lu S, Sahlol AT. New machine learning method for image-based diagnosis of COVID-19. PLoS One 2020;15(6):e0235187 [FREE Full text] [doi: 10.1371/journal.pone.0235187] [Medline: 32589673]

114. Hurt B, Kligerman S, Hsiao A. Deep learning localization of pneumonia. J Thorac Imaging 2020;35(3):W87-W89. [doi: 10.1097/rti.0000000000000512]

115. Joshi RP, Pejaver V, Hammarlund NE, Sung H, Lee SK, Furmanchuk A, et al. A predictive tool for identification of SARS-CoV-2 PCR-negative emergency department patients using routine test results. J Clin Virol 2020 Aug;129:104502 [FREE Full text] [doi: 10.1016/j.jcv.2020.104502] [Medline: 32544861] 
116. Kang H, Xia L, Yan F, Wan Z, Shi F, Yuan H, et al. Diagnosis of coronavirus disease 2019 (COVID-19) with structured latent multi-view representation learning. IEEE Trans Med Imaging 2020 Aug;39(8):2606-2614. [doi: 10.1109/TMI.2020.2992546] [Medline: $\underline{32386147]}$

117. Khan AI, Shah JL, Bhat MM. CoroNet: A deep neural network for detection and diagnosis of COVID-19 from chest X-ray images. Comput Methods Programs Biomed 2020 Dec;196:105581 [FREE Full text] [doi: 10.1016/j.cmpb.2020.105581] [Medline: 32534344]

118. Khuzani AZ, Heidari M, Shariati SA. COVID-Classifier: an automated machine learning model to assist in the diagnosis of COVID-19 infection in chest x-ray images. medRxiv 2020 May 18 [FREE Full text] [doi: 10.1101/2020.05.09.20096560] [Medline: $\underline{32511510]}$

119. Ko H, Chung H, Kang WS, Kim KW, Shin Y, Kang SJ, et al. COVID-19 pneumonia diagnosis using a simple 2D deep learning framework with a single chest CT image: model development and validation. J Med Internet Res 2020 Jun 29;22(6):e19569 [FREE Full text] [doi: 10.2196/19569] [Medline: 32568730]

120. Li L, Qin L, Xu Z, Yin Y, Wang X, Kong B, et al. Using artificial intelligence to detect COVID-19 and community-acquired pneumonia based on pulmonary CT: evaluation of the diagnostic accuracy. Radiology 2020 Aug;296(2):E65-E71 [FREE

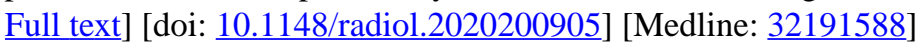

121. Mei X, Lee H, Diao K, Huang M, Lin B, Liu C, et al. Artificial intelligence-enabled rapid diagnosis of patients with COVID-19. Nat Med 2020 Aug 19;26(8):1224-1228 [FREE Full text] [doi: 10.1038/s41591-020-0931-3] [Medline: 32427924]

122. Murphy K, Smits H, Knoops AJG, Korst MBJM, Samson T, Scholten ET, et al. COVID-19 on chest radiographs: a multireader evaluation of an artificial intelligence system. Radiology 2020 Sep;296(3):E166-E172 [FREE Full text] [doi: 10.1148/radiol.2020201874] [Medline: 32384019]

123. Oh Y, Park S, Ye JC. Deep learning COVID-19 features on CXR using limited training data sets. IEEE Trans Med Imaging 2020 Aug;39(8):2688-2700. [doi: 10.1109/TMI.2020.2993291] [Medline: 32396075]

124. Panwar H, Gupta PK, Siddiqui MK, Morales-Menendez R, Singh V. Application of deep learning for fast detection of COVID-19 in X-Rays using nCOVnet. Chaos Solitons Fractals 2020 Oct;138:109944 [FREE Full text] [doi: 10.1016/j.chaos.2020.109944] [Medline: $\underline{32536759]}$

125. Pu J, Leader J, Bandos A, Shi J, Du P, Yu J, et al. Any unique image biomarkers associated with COVID-19? Eur Radiol 2020 Dec;30(11):6221-6227 [FREE Full text] [doi: 10.1007/s00330-020-06956-w] [Medline: 32462445]

126. Rahimzadeh M, Attar A. A modified deep convolutional neural network for detecting COVID-19 and pneumonia from chest X-ray images based on the concatenation of Xception and ResNet50V2. Inform Med Unlocked 2020;19:100360 [FREE Full text] [doi: 10.1016/j.imu.2020.100360] [Medline: 32501424]

127. Rajaraman S, Antani S. Training deep learning algorithms with weakly labeled pneumonia chest X-ray data for COVID-19

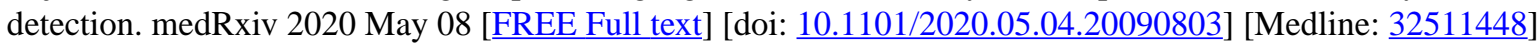

128. Roy S, Menapace W, Oei S, Luijten B, Fini E, Saltori C, et al. Deep learning for classification and localization of COVID-19 markers in point-of-care lung ultrasound. IEEE Trans Med Imaging 2020 Aug;39(8):2676-2687. [doi: 10.1109/TMI.2020.2994459] [Medline: 32406829]

129. Saiz F, Barandiaran I. COVID-19 detection in chest X-ray images using a deep learning approach. IJIMAI 2020;6(2):4. [doi: 10.9781/ijimai.2020.04.003]

130. Singh D, Kumar V, Vaishali, Kaur M. Classification of COVID-19 patients from chest CT images using multi-objective differential evolution-based convolutional neural networks. Eur J Clin Microbiol Infect Dis 2020 Jul 27;39(7):1379-1389 [FREE Full text] [doi: 10.1007/s10096-020-03901-z] [Medline: 32337662]

131. Al-Najjar H, Al-Rousan N. A classifier prediction model to predict the status of Coronavirus COVID-19 patients in South Korea. Eur Rev Med Pharmacol Sci 2020 Mar;24(6):3400-3403 [FREE Full text] [doi: 10.26355/eurrev_202003_20709] [Medline: $\underline{\text { 32271458] }}$

132. Burian E, Jungmann F, Kaissis G, Lohöfer F, Spinner CD, Lahmer T, et al. Intensive care risk estimation in COVID-19 pneumonia based on clinical and imaging parameters: experiences from the Munich cohort. SSRN Journal. 2020 Preprint posted online April 23. [doi: 10.2139/ssrn.3572889]

133. Chan L, Chaudhary K, Saha A, Chauhan K, Vaid A, Baweja M, et al. Acute kidney injury in hospitalized patients with COVID-19. medRxiv. 2020 Preprint posted online on May 8. [FREE Full text] [doi: 10.1101/2020.05.04.20090944] [Medline: 32511564$]$

134. Cheng Z, Qin L, Cao Q, Dai J, Pan A, Yang W, et al. Quantitative computed tomography of the coronavirus disease 2019 (COVID-19) pneumonia. Radiol Infect Dis 2020 Jul;7(2):55-61 [FREE Full text] [doi: 10.1016/j.jrid.2020.04.004] [Medline: 32346594]

135. Cheng F, Joshi H, Tandon P, Freeman R, Reich DL, Mazumdar M, et al. Using machine learning to predict ICU transfer in hospitalized COVID-19 patients. J Clin Med 2020 Jul 01;9(6) [FREE Full text] [doi: 10.3390/jcm9061668] [Medline: $\underline{32492874]}$

136. Du S, Gao S, Huang G, Li S, Chong W, Jia Z, et al. Chest lesion CT radiological features and quantitative analysis in RT-PCR turned negative and clinical symptoms resolved COVID-19 patients. Quant Imaging Med Surg 2020 Jul;10(6):1307-1317 [FREE Full text] [doi: 10.21037/qims-20-531] [Medline: 32550139] 
137. Ji M, Yuan L, Shen W, Lv J, Li Y, Chen J, et al. A predictive model for disease progression in non-severely ill patients with coronavirus disease 2019. Eur Respir J 2020 Jul;56(1) [FREE Full text] [doi: 10.1183/13993003.01234-2020] [Medline: $\underline{32430433]}$

138. Jiang X, Coffee M, Bari A, Wang J, Jiang X, Huang J. Towards an artificial intelligence framework for data-driven prediction of coronavirus clinical severity. Cmc-Computers Materials \& Continua 2020 Mar 30;63(1):537-551. [doi: $\underline{10.32604 / \mathrm{cmc} .2020 .010691]}$

139. Li MD, Arun NT, Gidwani M, Chang K, Deng F, Little BP, et al. Automated assessment of COVID-19 pulmonary disease severity on chest radiographs using convolutional Siamese neural networks. medRxiv. 2020 Preprint posted online on May 26. [FREE Full text] [doi: 10.1101/2020.05.20.20108159] [Medline: 32511570]

140. McRae MP, Simmons GW, Christodoulides NJ, Lu Z, Kang SK, Fenyo D, et al. Clinical decision support tool and rapid point-of-care platform for determining disease severity in patients with COVID-19. Lab Chip 2020 Jun 21;20(12):2075-2085. [doi: 10.1039/d0lc00373e] [Medline: $\underline{32490853]}$

141. Shashikumar SP, Wardi G, Paul P, Carlile M, Brenner LN, Hibbert KA, et al. Development and Prospective Validation of a Transparent Deep Learning Algorithm for Predicting Need for Mechanical Ventilation. medRxiv. 2020 Preprint posted online on June 03. [FREE Full text] [doi: 10.1101/2020.05.30.20118109] [Medline: 32577682]

142. Shen B, Yi X, Sun Y, Bi X, Du J, Zhang C, et al. Proteomic and metabolomic characterization of COVID-19 patient sera. Cell 2020 Jul 09;182(1):59-72.e15 [FREE Full text] [doi: 10.1016/j.cell.2020.05.032] [Medline: $\underline{32492406}$ ]

143. Wang Y, Chen Y, Wei Y, Li M, Zhang Y, Zhang N, et al. Quantitative analysis of chest CT imaging findings with the risk of ARDS in COVID-19 patients: a preliminary study. Ann Transl Med 2020 May;8(9):594 [FREE Full text] [doi: 10.21037/atm-20-3554] [Medline: $\underline{32566621]}$

144. Wang Y, Luo H, Liu S, Huang S, Zhou Z, Yu Q, et al. Dynamic evolution of COVID-19 on chest computed tomography: experience from Jiangsu Province of China. Eur Radiol 2020 Dec;30(11):6194-6203 [FREE Full text] [doi: 10.1007/s00330-020-06976-6] [Medline: $\underline{\text { 32524223] }}$

145. Wang S, Zha Y, Li W, Wu Q, Li X, Niu M, et al. A fully automatic deep learning system for COVID-19 diagnostic and prognostic analysis. Eur Respir J 2020 Aug;56(2) [FREE Full text] [doi: 10.1183/13993003.00775-2020] [Medline: $\underline{32444412]}$

146. Yadaw AS, Li Y, Bose S, Iyengar R, Bunyavanich S, Pandey G. Clinical predictors of COVID-19 mortality. medRxiv. 2020 Preprint posted online on May 22. [FREE Full text] [doi: 10.1101/2020.05.19.20103036] [Medline: $\underline{32511520]}$

147. Zhang K, Liu X, Shen J, Li Z, Sang Y, Wu X, et al. Clinically applicable ai system for accurate diagnosis, quantitative measurements, and prognosis of COVID-19 pneumonia using computed tomography. Cell 2020 Jun 11;181(6):1423-1433.e11 [FREE Full text] [doi: 10.1016/j.cell.2020.04.045] [Medline: $\underline{32416069]}$

148. Wollenstein-Betech S, Cassandras CG, Paschalidis IC. Personalized predictive models for symptomatic COVID-19 patients using basic preconditions: hospitalizations, mortality, and the need for an ICU or ventilator. medRxiv 2020 May 08 [FREE Full text] [doi: 10.1101/2020.05.03.20089813] [Medline: 32511489]

149. Song Y, Zhang M, Yin L, Wang K, Zhou Y, Zhou M, et al. COVID-19 treatment: close to a cure? A rapid review of pharmacotherapies for the novel coronavirus (SARS-CoV-2). Int J Antimicrob Agents 2020 Aug;56(2):106080 [FREE Full text] [doi: 10.1016/j.ijantimicag.2020.106080] [Medline: 32634603]

150. Mohanty S, Harun Ai Rashid M, Mridul M, Mohanty C, Swayamsiddha S. Application of artificial intelligence in COVID-19 drug repurposing. Diabetes Metab Syndr 2020;14(5):1027-1031 [FREE Full text] [doi: 10.1016/j.dsx.2020.06.068] [Medline: 32634717]

151. Pandey A, Nikam AN, Shreya AB, Mutalik SP, Gopalan D, Kulkarni S, et al. Potential therapeutic targets for combating SARS-CoV-2: Drug repurposing, clinical trials and recent advancements. Life Sci 2020 Oct 01;256:117883 [FREE Full text] [doi: 10.1016/j.lfs.2020.117883] [Medline: 32497632$]$

152. Réda C, Kaufmann E, Delahaye-Duriez A. Machine learning applications in drug development. Computational and Structural Biotechnology Journal 2020;18:241-252 [FREE Full text] [doi: 10.1016/j.csbj.2019.12.006]

153. Jin Z, Du X, Xu Y, Deng Y, Liu M, Zhao Y, et al. Structure of M from SARS-CoV-2 and discovery of its inhibitors. Nature 2020 Jun;582(7811):289-293. [doi: 10.1038/s41586-020-2223-y] [Medline: 32272481]

154. Li G, De Clercq E. Therapeutic options for the 2019 novel coronavirus (2019-nCoV). Nat Rev Drug Discov 2020 Mar;19(3):149-150. [doi: 10.1038/d41573-020-00016-0] [Medline: 32127666]

155. Ullrich S, Nitsche C. The SARS-CoV-2 main protease as drug target. Bioorg Med Chem Lett 2020 Sep 01;30(17):127377 [FREE Full text] [doi: 10.1016/j.bmcl.2020.127377] [Medline: $\underline{32738988]}$

156. Zhao K, So H. A machine learning approach to drug repositioning based on drug expression profiles: Applications in psychiatry. arXiv. 2017 Preprint posted online Dec 12.

157. Zielezinski A, Vinga S, Almeida J, Karlowski WM. Alignment-free sequence comparison: benefits, applications, and tools. Genome Biol 2017 Oct 03;18(1):186 [FREE Full text] [doi: 10.1186/s13059-017-1319-7] [Medline: 28974235]

158. Vinga S, Almeida J. Alignment-free sequence comparison-a review. Bioinformatics 2003 Mar 01;19(4):513-523. [doi: 10.1093/bioinformatics/btg005] [Medline: 12611807] 
159. Moradian N, Ochs HD, Sedikies C, Hamblin MR, Camargo CA, Martinez JA, et al. The urgent need for integrated science to fight COVID-19 pandemic and beyond. J Transl Med 2020 May 19;18(1):205 [FREE Full text] [doi: 10.1186/s12967-020-02364-2] [Medline: $\underline{\text { 32430070] }}$

160. Melissa H, Christopher C, Kenneth G. The National COVID Cohort Collaborative (N3C): rationale, design, infrastructure, and deployment. J Am Med Inform Assoc 2020 Aug 17 [FREE Full text] [doi: 10.1093/jamia/ocaa196] [Medline: 32805036]

161. Dubey S, Biswas P, Ghosh R, Chatterjee S, Dubey MJ, Chatterjee S, et al. Psychosocial impact of COVID-19. Diabetes Metab Syndr 2020;14(5):779-788 [FREE Full text] [doi: 10.1016/j.dsx.2020.05.035] [Medline: 32526627]

162. Janz NK, Becker MH. The Health Belief Model: a decade later. Health Educ Q 1984;11(1):1-47. [doi: 10.1177/109019818401100101] [Medline: 6392204]

163. Devlin J, Chang M, Lee K, Toutanova K. BERT: Pre-training of Deep Bidirectional Transformers for Language Understanding. In: Proceedings of the 2019 Conference of the North American Chapter of the Association for Computational Linguistics: Human Language Technologies, Volume 1 (Long and Short Papers). Minneapolis, MN: Association for Computational Linguistics; Jun 2019.

164. Yang Z, Dai Z, Yang Y, Carbonell J, Salakhutdinov R, Le Q. XLNet: Generalized autoregressive pretraining for language understanding. 2019 Dec 12 Presented at: 33rd Conference on Neural Information Processing Systems (NeurIPS 2019); Dec 12, 2019; Vancouver, BC URL: https://proceedings.neurips.cc/paper/2019/file/ dc6a7e655d7e5840e66733e9ee67cc69-Paper.pdf

165. Ivorra B, Ferrández MR, Vela-Pérez M, Ramos AM. Mathematical modeling of the spread of the coronavirus disease 2019 (COVID-19) taking into account the undetected infections. The case of China. Commun Nonlinear Sci Numer Simul 2020 Sep;88:105303. [doi: 10.1016/j.cnsns.2020.105303] [Medline: $\underline{32355435]}$

166. Wang N, Fu Y, Zhang H, Shi H. An evaluation of mathematical models for the outbreak of COVID-19. Precis Clin Med 2020 May 22;3(2):85-93. [doi: 10.1093/pcmedi/pbaa016]

167. Anirudh A. Mathematical modeling and the transmission dynamics in predicting the Covid-19 - What next in combating the pandemic. Infect Dis Model 2020;5:366-374 [FREE Full text] [doi: 10.1016/j.idm.2020.06.002] [Medline: $\underline{32666005}$ ]

168. Jewell NP, Lewnard JA, Jewell BL. Caution warranted: using the institute for health metrics and evaluation model for predicting the course of the COVID-19 pandemic. Annals of Internal Medicine 2020 Aug 04;173(3):226-227. [doi: $10.7326 / \mathrm{m} 20-1565]$

169. Long C, Xu H, Shen Q, Zhang X, Fan B, Wang C, et al. Diagnosis of the Coronavirus disease (COVID-19): rRT-PCR or CT? Eur J Radiol 2020 May;126:108961 [FREE Full text] [doi: 10.1016/j.ejrad.2020.108961] [Medline: 32229322]

170. Zhai P, Ding Y, Wu X, Long J, Zhong Y, Li Y. The epidemiology, diagnosis and treatment of COVID-19. Int J Antimicrob Agents 2020 May;55(5):105955 [FREE Full text] [doi: 10.1016/j.ijantimicag.2020.105955] [Medline: 32234468]

171. Ai T, Yang Z, Hou H, Zhan C, Chen C, Lv W, et al. Correlation of Chest CT and RT-PCR Testing for Coronavirus Disease 2019 (COVID-19) in China: A Report of 1014 Cases. Radiology 2020 Aug;296(2):E32-E40 [FREE Full text] [doi: 10.1148/radiol.2020200642] [Medline: 32101510]

172. Xu B, Xing Y, Peng J, Zheng Z, Tang W, Sun Y, et al. Chest CT for detecting COVID-19: a systematic review and meta-analysis of diagnostic accuracy. Eur Radiol 2020 Oct;30(10):5720-5727 [FREE Full text] [doi: 10.1007/s00330-020-06934-2] [Medline: 32415585]

173. Kim YY, Shin HJ, Kim MJ, Lee M. Comparison of effective radiation doses from X-ray, CT, and PET/CT in pediatric patients with neuroblastoma using a dose monitoring program. Diagn Interv Radiol 2016;22(4):390-394 [FREE Full text] [doi: 10.5152/dir.2015.15221] [Medline: 27306659]

174. Sistrom CL, McKay NL. Costs, charges, and revenues for hospital diagnostic imaging procedures: differences by modality and hospital characteristics. J Am Coll Radiol 2005 Jul;2(6):511-519. [doi: 10.1016/j.jacr.2004.09.013] [Medline: 17411868]

175. Wong MD, Thai T, Li Y, Liu H. The role of chest computed tomography in the management of COVID-19: A review of results and recommendations. Exp Biol Med (Maywood) 2020 Jul;245(13):1096-1103. [doi: 10.1177/1535370220938315] [Medline: $\underline{32588660}$ ]

176. Trauer M, Matthies A, Mani N, McDermott C, Jarman R. Utility of lung ultrasound in COVID-19: a systematic scoping review. medRxiv. 2020 Preprint posted online on June 17. [doi: 10.1101/2020.06.15.20130344]

177. Poggiali E, Dacrema A, Bastoni D, Tinelli V, Demichele E, Mateo Ramos P, et al. Can lung us help critical care clinicians in the early diagnosis of novel coronavirus (COVID-19) pneumonia? Radiology 2020 Jun;295(3):E6 [FREE Full text] [doi: 10.1148/radiol.2020200847] [Medline: $\underline{32167853}$ ]

178. Gong Y, Ma T, Xu Y, Yang R, Gao L, Wu S, et al. Early research on COVID-19: a bibliometric analysis. Innovation (N Y) 2020 Aug 28;1(2):100027 [FREE Full text] [doi: 10.1016/j.xinn.2020.100027] [Medline: 32914141]

179. Hick JL, Hanfling D, Wynia MK, Pavia AT. Duty to plan: health care, crisis standards of care, and novel coronavirus SARS-CoV-2. NAM Perspectives 2020 Mar 5. [doi: 10.31478/202003b]

180. Liu C, Wang X, Liu C, Sun Q, Peng W. Differentiating novel coronavirus pneumonia from general pneumonia based on machine learning. Biomed Eng Online 2020 Aug 19;19(1):66 [FREE Full text] [doi: 10.1186/s12938-020-00809-9] [Medline: $\underline{32814568]}$

181. Blomberg N, Lauer KB. Connecting data, tools and people across Europe: ELIXIR's response to the COVID-19 pandemic. Eur J Hum Genet 2020 Jun;28(6):719-723 [FREE Full text] [doi: 10.1038/s41431-020-0637-5] [Medline: 32415272] 
182. Chen D, Liu S, Kingsbury P, Sohn S, Storlie CB, Habermann EB, et al. Deep learning and alternative learning strategies for retrospective real-world clinical data. NPJ Digit Med 2019;2:43 [FREE Full text] [doi: 10.1038/s41746-019-0122-0] [Medline: $\underline{31304389}$ ]

183. Clark K, Vendt B, Smith K, Freymann J, Kirby J, Koppel P, et al. The Cancer Imaging Archive (TCIA): maintaining and operating a public information repository. J Digit Imaging 2013 Dec;26(6):1045-1057 [FREE Full text] [doi: 10.1007/s10278-013-9622-7] [Medline: 23884657]

\title{
Abbreviations
}

AI: artificial intelligence

ALT: alanine aminotransferase

ARDS: acute respiratory distress syndrome

ARIMA: auto-regressive integrated moving average

AUC: area under the curve

AUROC: area under the receiver operating characteristics

CDT: COVID-19 disease trajectory

CE: computational epidemiology

CT: computed tomography

CXR: chest X-ray

DL: deep learning

DP: disease progression

EDD: early detection and diagnosis

EHR: electronic health record

FCR: facilitate COVID-19 response

HBM: health belief model

ICU: intensive care unit

LSTM: long-short term memory

LUS: lung ultrasound

MADD: molecular analysis-drug discovery

ML: machine learning

Mpro: main protease

MRI: magnetic resonance imaging

N3C: National COVID Cohort Collaborative

NLP: natural language processing

PRISMA: Preferred Reporting Items for Systematic Reviews and Meta-analysis

RT-PCR: reverse transcription-polymerase chain reaction

SEIR: specifically, susceptible-exposed-infectious-recovered

X-ray: X-radiation

\author{
Edited by C Lovis; submitted 24.08.20; peer-reviewed by J Ye, I Apostolopoulos, AS Pawar, Z Ren; comments to author 06.10.20; \\ revised version received 27.10.20; accepted 15.11.20; published 11.01.21 \\ Please cite as: \\ Syeda HB, Syed M, Sexton KW, Syed S, Begum S, Syed F, Prior F, Yu Jr F \\ Role of Machine Learning Techniques to Tackle the COVID-19 Crisis: Systematic Review \\ JMIR Med Inform 2021;9(1):e23811 \\ URL: http://medinform.jmir.org/2021/1/e23811/ \\ doi: $\underline{10.2196 / 23811}$ \\ PMID: 33326405
}

CHafsa Bareen Syeda, Mahanazuddin Syed, Kevin Wayne Sexton, Shorabuddin Syed, Salma Begum, Farhanuddin Syed, Fred Prior, Feliciano Yu Jr. Originally published in JMIR Medical Informatics (http://medinform.jmir.org), 11.01.2021. This is an open-access article distributed under the terms of the Creative Commons Attribution License (https://creativecommons.org/licenses/by/4.0/), which permits unrestricted use, distribution, and reproduction in any medium, provided the original work, first published in JMIR Medical Informatics, is properly cited. The complete bibliographic information, a link to the original publication on http://medinform.jmir.org/, as well as this copyright and license information must be included. 